\title{
Shaping the Enemy:
}

\section{Foundational Labelling by L.E.J. Brouwer and A. Heyting}

\author{
By Miriam Franchella - Università degli Studi - Dipartimento di Studi Storici - \\ Via Festa del Perdono 7 - 20122 Milano - Italy - email: miriam.franchella@ unimi.it
}

\begin{abstract}
The use of the three labels (logicism, formalism, intuitionism) to denote the three foundational schools of the early twentieth century are now part of literature. Yet, neither their number nor their adoption has been stable over the twentieth century. They were not introduced by the founding fathers of each school: namely, neither Frege nor Russell spoke of 'logicism'; and even Hilbert did not use the word 'formalism' to introduce his foundational programs. At a certain point, only Brouwer used the label 'intuitionism' in his scientific production to personify his philosophy of mathematics and he used the label 'formalism' for Hilbert's foundational viewpoint. Starting with Brouwer, the origin of the use of the three labels to represent a foundational meaning, will be analysed in this paper. Thereafter, the role that Brouwer's pupil Arend Heyting had in the production and use of foundational labels will be considered. On the basis of the comparison of the attitudes of these two scholars I will finally advance the thesis that not only the creation but also the use of labels, far from being a mere gesture of academic reference to literature, can be a sign of the cultural operation each scholar wanted to do.
\end{abstract}

Keywords: history of logic, foundations of mathematics, logicism, intuitionism, formalism.

\section{Introduction}

In this paper we will see the role and the attitude that Luitzen Egbertus Jan Brouwer and Arend Heyting have had in the production and use of the three foundational labels (logicism, formalism, intuitionism) after a very intriguing series of events. It begins with Brouwer's dissertation (1907). Brouwer used the labels at hand in the 'foundational market' (i.e. those mentioned in the mathematical/philosophical journals by Cantor, Poincaré, Hilbert, Couturat, Russell), such as: 'axiomatics', 'Cantorianism'1 and 'logistics' (as proposed by Couturat). We do not find 'logicism', because this foundational label only appeared in 1928, nor do we find intuitionism, because Brouwer had not chosen any for his viewpoint.

\section{Brouwer's thesis}

In his $\mathrm{Ph}$. D. thesis, Brouwer analyzed ${ }^{2}$ the various foundational approaches starting from his own: which was the correct one and the differences that lay in it explained the failure of all the other approaches. He began with an analysis of his viewpoint about mathematics: it consisted of mental constructions and was independent from logical laws, although it 'is expressed in the form of argumentation, deduction of properties, by means of a chain of syllogisms'. Even proof by contradiction (reductio ad absurdum) requires a construction, namely one begins a construction (according to the definitions expressed in the theorem) which at a certain point can no longer go; even in this case, one observes something, he does not think of a law: 'I simply perceive that the construction no longer goes, that the required structure cannot be imbedded in the given basic structure. And when I make this observation, I do not think of a principium contradictionis' (CW I, p. 73).

After such mental constructions are performed, there can be the will or the need to describe them to other people so that they themselves can build something analogous and, by looking at the linguistic expression of mathematical constructions, it is possible to discover a regularity in the combination of words: 'Here a

\footnotetext{
${ }^{1}$ To be more precise, 'axiomaticians' and 'Cantorians'.
}

${ }^{2}$ About Brouwer's thesis see van Stigt 1990, pp. 35-43. 
mathematical system is projected and the man calls such sentence an application of a logical law' ( $C W I$, p. 75). The mathematical study of this part of mathematical language is called by Brouwer 'theoretical logic'. The mathematical study of the whole of mathematical language is 'the content of logistic'. It can be traced back to Leibniz but it has been fully developed 'in the last twenty years' ( $C W I$, p. 74). Both theoretical logic and logistic are considered by Brouwer as empirical sciences as they are applied mathematics, and for this reason they do not give us any information about the organization and functioning of the human intellect: 'There would be better reason to reckon them under ethnography than under psychology'. Moreover, 'The idea that by means of such linguistic structures we can obtain knowledge of mathematics apart from that which can be constructed by direct intuition, is mistaken' ( $C W I$, p. 75).

On this basis, he began to analyse the various foundations of mathematics of his time: 1) foundations on axioms, 2) Cantor's transfinite numbers, 3) the Peano-Russell logistic, 4) the logical foundation after Hilbert.

The first field concerned recent researches by Pasch, Schur, Hilbert, Peano, Pieri and pointed out some 'failings' within Euclidean geometry: axioms are tacitly introduced here and there. However, Brouwer stigmatized that their targets were not Euclidean imperfections, but pathological geometries. They constructed linguistic structures and required proof of consistency, but nobody proved that consistency was a sufficient condition to exist mathematically.

The second field that Brouwer considered was Cantorianism, that he criticized because 'Cantor loses contact with the firm ground of mathematics' (CWI, p. 81) in his definition of the second number class. ${ }^{3}$ In particular, in the concept of 'den Inbegriff aller' he mentioned something which cannot be thought of, for a totality constructed by means of 'and so on' could only be thought of if 'and so on' refers to an ordertype $\omega$ of equal objects, and this was not the case.

Then he focuses on Peano and Russell's treatment of logic. Brouwer saw it as an attempt to put a remedy on the fact that classical logic is inadequate for mathematics (CWI, p. 89):

The logisticians, considering the propositional functions as the free origin of logic and mathematics, utter as such various sentences which are built in (falsely presumed) analogy to mathematical properties, and they postulate that these sentences define classes and that it is allowed to reason about these classes according to the laws of classical logic.

Brouwer also affirmed (CWI, p. 88):

But in the intellect one cannot give a linguistic system of statements and propositional functions priority over mathematics, for no assertions about the external world can be intelligently made besides those that presuppose a mathematical system that has been projected on the external world.

Therefore, it is not surprising that they, like the Cantorians, collided against contradictions. As for the extension of classical logic represented in 'logistics' by the logic of relations, Brouwer stated (CW I, p. 90): 'It is selfevident that in the language which accompanies mathematics, the succession of words obeys certain laws, but to consider these laws as directing the building up of mathematics, it is therein that the mistake lies'.

The conclusion that he drew about logistics was that it was not suitable as foundation of mathematics because it was separate from mathematics. The best to which it could aim was being a faithful stenographic copy of the language of mathematics 'which itself is not mathematics but no more than a defective expedient for men to communicate mathematics to each other and to aid their memory for mathematics' ( $C W I$, p. 92).

Thereafter he turned to Hilbert, who gave 'the most uncompromising conclusion of the methods we attack, which illustrates most lucidly their inadequacy' ( $C W I$, p. 92). In particular, Hilbert aimed at achieving consistency proofs for various parts of mathematics. He aspired to start from nothing and to develop

\footnotetext{
3 Brouwer (CW I, p. 81) quoted Cantor's definition:
}

Wir definiren die zweite Zahlenklasse als den Inbegriff aller mit Huelfe der beiden Erzeugungsprinzipe (he means by those principles: add one unit and: take for an ordertype $w$ the next higher element, the limit-element) bildbaren, in bestimmter Succession fortschreitenden Zahlen: $\omega, \omega+1, v_{0} \omega^{\mu}+v_{1} \omega^{\mu-1}+\ldots+v_{\mu-1} \omega+v_{\mu}, \ldots, \omega^{\omega}, \ldots, \alpha, \ldots$ welche die Bedingung unterworfen sind, dass alle der Zahl $\alpha$ voraufgehenden Zahlen, von 1 an, eine Menge von der Mächtigkeit der ersten Zahlenclasse bilden. 
mathematics and logic together, but he intuitively applied all the laws of logic and even complete induction (CW I, p. 93). Furthermore, the consistency of the linguistic system, deduced by means of the mathematical intuition, did not prove the mathematical intuition. Finally, he stressed that Hilbert was even more open to criticism than 'the logicians' because in his works there was list of confusing stages: ${ }^{4}$

1. Construction of intuitive mathematical systems

2. Mathematical speaking or writing (the expression of 1)

3. The mathematical study of language: 'we notice logical linguistic structures, raised according to principles from ordinary logic or through the logic of relations'.

4. Forgetting the sense of the elements of the logical figures in 2. and imitating the construction of these figures by a new mathematical system of second order.

5. The language that may accompany 4 .

6. The mathematical study of language 5 .

7. Forgetting the sense of the elements of the logical figures in 5. and imitating the construction of these figures by a new mathematical system of third order.

8. The language that may accompany 7 .

In each paragraph of Hilbert's 'Über den Zahlbegriff' (1900a) he pointed what stage Hilbert referred to exactly, and when he jumped from one stage to another.

Brouwer believed that Poincaré criticized both logistics and Cantorianism, by blaming the petitio principii in the former and the reference to the actual infinite in the latter. According to Brouwer, Poincare only dealt with the surface of the matter and not the core, hereby the confusion between the act of constructing mathematics and the language that accompanies it. Poincare did not found mathematics on construction. In particular, he wrote ( $C W$ I, p. 96): 'Le mathématiques sont indépendantes de l'existence des objets matériels; en mathématiques le mot exister ne peut avoir qu'un sens, il signifie exempt de contradiction'.

It is important to underline that in Brouwer's dissertation, Frege was not mentioned. In the first volume of Brouwer's Collected Works, on p. 568 in the footnote Heyting, as the editor, stated: 'Brouwer seems not to have known Frege's work. He has never mentioned it'. Kuiper (2004, p. 223) stated:

That Brouwer was at least familiar with some of Frege's work and can be concluded from the following: in the first place, he attended the lectures by Mannoury who discussed Frege's work on the foundations of mathematics; (cf. Mannoury 1909, Vorwort and page $78 \mathrm{ff}$.); secondly, Brouwer referred on one occasion in notebook ${ }^{5} 8$ to an article by Frege in the Jahresbericht der Deutschen Mathematiker Vereinigung number 12, Über die Grundlagen der Geometrie II, in which Frege 1903 reacted on Hilbert's book with the same title. ${ }^{6}$ In his Synopsis of the notebooks Brouwer again referred to the relevant paragraph in notebook 8.

Nevertheless, Brouwer believed that Russell not Frege was his target in 'logistics'. Kuiper stressed that in 1907, Frege 1884 and Frege 1893 were both available at the University of Amsterdam library according to information acquired by the University Library (Kuiper 2004, p. 223). Frege's work was neglected by mathematicians of that time, presumably because the symbolism he used was rather forbidding, and Russell's influence was far greater and hence he was often read instead.

\section{Around 1912}

In 1908, in the article where he criticized the principle of the excluded middle, Brouwer referred to foundational schools by stating that recent paradoxes created skepticism in the free use of logic in mathematics, therefore some mathematicians abandoned the idea that logic is presupposed in mathematics and tried to build

\footnotetext{
${ }^{4}$ Brouwer stated that, even if it were possible to go further on, it would be senseless, because the mathematical systems of higher orders would simply be copies of these.

${ }^{5}$ Brouwer's notebooks are now available at: http://www.cs.ru.nl/ freek/brouwer/ with a transcription by John Kuiper.

${ }^{6}$ Hilbert 1899.
} 
both sciences in parallel by using 'the methods of logistics, founded by Peano' (CW I, p. 108). He concluded by stating that the basic intuition of mathematics was unavoidable, and we should attain to what can be developed from it, but he did not coin a label for his viewpoint.

It was only in the 1911 review of the Mannoury volume Methodologisches und Philosophisches zur ElementarMathematik that Brouwer suddenly introduced (CW I, p. 121) the contrast between intuitionism vs formalism (it wasn't in Mannoury's book) ${ }^{7}$ :

[...] the author defends the 'formalist' concept, which has also been advocated by Dedekind, Peano, Russell, Hilbert and Zermelo, against 'intuitionists' like Poincaré and Borel for instance. This formalist concept recognizes no other mathematics than the mathematical language and it considers it essential to draw up definitions and axioms and to deduce these other propositions by means of logical principles which are also explicitly formulated beforehand.

After defining formalism, Brouwer wondered what could have been the reason for accepting those axioms and mentioned Russell's answer which was to verify the logical existence of mathematical entities and Hilbert's answer which was to verify the logical figure of 'contradiction' that could not be derived by the axioms. ${ }^{8} \mathrm{He}$ ended by emphasizing that both Russell and Hilbert could not do without 'the intuitive application of complete induction' and therefore 'they have invigorated by their reasoning rather intuitionism than formalism' (CW I, p. 121). Furthermore, he added that Mannoury could criticise intuitionism because he only had Poincaré's version of it, and this produced two weak points: the rejection of every infinite number, including the denumerable, and the identification of mathematical existence with non-contradictoriness. Brouwer was sure that 'it is only after these mistakes have been redressed, and after the basic intuition of two-ity has been accepted, that intuitionism becomes invulnerable' (CWI, p. 122). In Mannoury's book two opposite viewpoints about mathematics are described: Kantianismus and Symbolismus. 'Thus, the question arises how Brouwer came to employ these names', Hesseling affirmed (2003, p. 53). He presented three possible explanations for the label 'intuitionism': 1) Brouwer coined the term influenced by Kant, Schopenhauer and Poincaré; 2) he took the term from Felix Klein or Henri Bergson; 3) he got the term from morality theory (such use was supported by Clausberg and Dubislav 1923'). As for the label 'formalism', Hesseling (2003, pp. 52-53) stressed that "Frege [...] argued strongly against Thomae's views, using words such as "formal" and "formal arithmetiker", but he did not call Thomae's view "formalism"'. Nor do we know if Brouwer actually knew anything about such dispute. Hesseling concluded (2003, p. 54):

Whatever the origin of the names may be, it is a fact that in the 1920s people involved in the foundational debate saw the terms 'intuitionism' and 'formalism' as coined by Brouwer. Bernays, looking back at the

\footnotetext{
${ }^{7}$ Mancosu 1998, p.180 was the first to notice that Brouwer's introduction of the two labels had taken place in 1911 (and not in 1912, in his first academic lecture, as its title would suggest); Hesseling 2003, p. 52 specified that the labels came from Brouwer himself and not from Mannoury's book, as the review could suggest.

${ }^{8}$ As for Mannoury, Brouwer said that his formalism was untenable, but he justified his criticism through his own point of view about mathematics. Indeed, he stated that Mannoury had based the choice of axioms on psychology, but 'like every science of experience psychology presupposes mathematics at least up to the first infinite cardinal number inclusive' (CW I, p. 121).

${ }^{9}$ The two authors proposed a classification of ethical theories according to the question they intend to answer, i.e. the question about the origin of ethical norms and the question about the essence of ethical norms. 'Intuitionism' was a kind of answer to the first question (it was a nuance of the empiricist answer to that question), defined as follows: "eine Lehre der Ethik heißt "nativistische" oder 'intuitionistische', der zufolge die ethischen Normen angeboren und nicht erworben sind' (1923, p.161). Hesseling found this innatism very similar to Brouwer's primordial intuition. Furthermore, the Clausbeg-Dubislav definition of formalism, like Brouwer's one, intended as a way of proceeding without attention to the content of involved concepts. Therefore, Hesseling seemed to be inclined toward this explanation: 'The strong point in this explanation is that not only accounts for Brouwer's choice in the name of intuitionism, but also of formalism' (2003, pp. 54-55). Yet, he added: 'However, I have not found any explicit reference to intuitionism in ethics in Brouwer's writings' (2003, p. 54).

It is interesting to point out that also the label 'logicism' appeared in the Woerterbuch.
} 
debate from the 1970s, even claimed that all three terms - intuitionism, formalism and logicism originated from Brouwer.

In order to consider the matter in detail, we must mention Felix Klein's first Evanston lecture (1893, p.2) where he placed mathematicians in three main categories: logicians, formalists and intuitionists:

the word logician is here used, of course, without reference to the mathematical logic of Boole, Peirce, etc.; it is only intended to indicate that the main strength of the men belonging to this class lies in their logical and critical power, in their ability to give strict definitions, and to derive rigid deductions therefrom.

He quoted Karl Weierstrass as an example. Then, he stated that the formalists mainly excelled in the formal usage of a given question, "in devising for it an "algorithm"'. He used Paul Gordan, Arthur Cayley and James Sylvester as examples. Finally, he wrote $\left(1893\right.$, p. 3): 'To the intuitionists ${ }^{10}$ belong those who lay particular stress on geometrical intuition ('Anschauung'), not in pure geometry only, but in all branches of mathematics. What Benjamin Peirce has called 'geometrizing a mathematical question' seems to express the same idea'.

Lord Kelvin and Karl von Staudt were examples. We see that the labels 'formalism' and 'Intuitionism' are coined but their meanings are different to Brouwer's ones.

In his book, Mannoury introduced the contraposition Kantianism/Symbolism in the index (1909, p. 262), in the third group of topics in the first chapter (of the second part of the book) about mathematical logic: 'Kritik des Symbolischen Logik; die Beurteilung der Widerspruchslosigkeit der logischen Formeln; Kantianismus und Symbolismus'. In the inner pages of the book we find 'Kantianismus' as committed mainly to Poincaré, defined as 'der talentvolle Wortführer des Kantianismus in der Mathematik' (1909, p. 144). The authors quoted on the opposite side were Giuseppe Peano, Louis Couturat and Hilbert. 'Symbolismus' was explicitly named (1909, p. 149) as a 'Werkzeug' for a better understanding of judgements, when Mannoury expressed his own opinion about non-contradictoriness of formal systems. In particular, Mannoury believed in the impossibility of individuating elements both inside nature and inside consciousness: they are continuous. More specifically, every element of consciousness is in infinite ways related to former elements (remembrances) and to future elements (expectations). Only on a conventional level (with an aimed target) can we decide to point out elements and the special relationships between them. Language could help us, on a conventional level to keep our elements fixed. Therefore, mathematics, with its unities, had no intrinsic exactness, but unity could be an arbitrarily chosen element of consciousness. Hence, mathematics was founded on psychology. The stability of mathematics was better sustained by forms of language that have strong stability, i.e. symbolic language. Consequently, Mannoury, among symbolism and Kantianism, was a symbolist, but on a realistic level (he referred both to Hegel and Nietzsche): mathematics was a human product, containing only relative truths, i.e. truths relative to human purposes and languages. ${ }^{11}$ He specified that non-contradictoriness was not the warranty of mathematical certainty, of mathematical absolute truth, because truth/falsity are always relative, ${ }^{12}$ the task of explaining why we are so averse to contradictory systems belongs to psychology. ${ }^{13}$ In a footnote

${ }^{10}$ In his sixth lecture, on the purpose of intuition of space, Klein wrote (1893, p. 46):

Finally, it must be said that the degree of exactness of the intuition of space may be different in different individuals, perhaps even in different races. It would see as if a strong naïve space-intuition were an attribute preeminently of the Teutonic race, while the critical, purely logical sense is more fully developed in the Latin and Hebrew races. A full investigation of this subject, somewhat on the lines suggested by Francis Galton in his researches on heredity, might be interesting.

${ }^{11}$ Heijerman 1990 p.267 defines Mannoury's position as 'formalistic, materialistic, psychologistic and pragmatic'.

${ }^{12}$ On this subject see Heijerman 1990.

${ }^{13}$ In 1917 Mannoury adhered to the Signific movement (and its related analysis of language). This determined a certain evolution towards intuitionism. Significs was defined by Mannoury (Heyting 1934, p. 290) as 'the theory of mental associations which underly human speech acts' and a speech act is every act with which people try to influence each other's conduct. Mannoury concentrated on verbal speech acts. He accepted Brouwer's opinion that all linguistic expressions are verbal imperatives, but he distinguished two kinds of speech acts, according on how much the satisfaction of the speaker depends on the willgness (or unwillingness) of the hearer to 'obey'. When satisfaction depends on this, the speech act represents an expression of willingness; otherwise it is an informative or indicative speech act. The signific 
(1909, p. 152) Mannoury said that among other (unnamed) Kantianer was Aurel Edmund Voss, according to what he sustained in his 1908 lecture 'Über das Wesen der Mathematik'. In particular, Voss defended 'die "höhere" Bedeutung der Mathematik, dem Formalismus gegenüber'. Therefore, the label 'Formalismus' for the enemies of the 'Kantianismus' was in that footnote. Thus, it could have been a direct source for Brouwer's choice of labels. We could imagine that Brouwer decided to change the label 'Kantianismus' for his foundational school in order to point out the originality of his own opinion (even though he admitted his 'debt' towards Kant). Since the intuition of two-ity had been used by him as the key for granting the invulnerability of his opinion, it seems reasonable that he used the label 'intuitionism', even though it had a different meaning in Klein's work. Then, once he had decided to change the core of the two labels (i.e. Kantianism), it was natural to change the other (symbolism), which was more 'unstable' inside the book and had already been substituted by 'formalism' in a footnote.

In 1912, in his introductory lecture 'Intuitionism and Formalism', Brouwer stated that there were two main points of view that founded the exactness of mathematics: 'The question where mathematical exactness does exist, is answered differently by the two sides; the intuitionist says: in the human intellect; the formalist says: on paper' ( $C W I$, p. 125). He traced an old form of intuitionism back to Kant, but also added that Kant's intuitionism was weak. It became more realistic when he abandoned apriority of space and built mathematics only on intuition of time. Brouwer described formalists as scholars starting from the theory that exact images of straight lines or of large numbers (numbers larger than three, for example) are not available to reason. Then they concluded that such entities 'do not have existence in our conception of nature any more than in nature itself', but they based their non-mathematical conviction of legitimacy of their systems on the efficacy of their projection into nature (CW I, p. 125):

For the formalist, therefore, mathematical exactness consists merely in the method of developing the series of relations [...] And for the consistent formalist these meaningless series of relations to which mathematics are reduced have mathematical existence only when they have been represented in spoken or written language together with the mathematical-logical laws upon which their development depends, thus forming what is called symbolic logic.

In order to be sure of the consistency of the language that they used, formalists avoided daily language and introduce new ones. Peano is labelled as a formalist, his symbolism is criticized as something that can only be read by a few of the initiated ( $C W I$, p. 126). According to Brouwer, intuitionists and formalists agreed on finite sets: in that field the two differ solely in their method, not in their results. On the contrary, when infinite sets are considered, 'the formalist introduces various concepts, completely meaningless to the intuitionist, such as "the set whose elements are the points of space", "the set whose elements are the continuous functions of a variable", etc.' (CW I, p. 130). Brouwer ended his lecture by stating that he saw no chance that an agreement in a finite period could be reached. He quoted Poincaré: 'Les hommes ne s'entendent pas, parce qu'ils ne parlent pas le même langue et qu'il y a des langues qui ne s'apprennent pas' (CW I, p. 138).

\section{Brouwer in $\mathbf{1 9 2 7}$}

1927 was the year of Brouwer's Berliner Gastvorlesungen. In 1991 van Dalen published Brouwer's manuscripts of lessons (Brouwer 1991). The same structure can be read in the postwar years, when Brouwer, after a long pause caused by his falling out with Hilbert (see van Dalen 1990), began to publish and lecture around the world. In the first chapter on 'Historische Stellung des Intuitionismus', he distinguished three

meaning of each speech act consists of the associations complement those acts. Associations resulting from observations are the indicative elements of the meaning; associations which relate to impulses and affects are the emotional elements of the meaning. Furthermore, there are volitional and formal elements. Mannoury built a hierarchy of linguistic levels, on the basis of an increasing stability of word connection. The application of this analysis to mathematics led Mannoury to see the possibility of a distinction between indicative and emotional elements also in mathematics: the indicative meaning of mathematical theorems consists of the knowledge of formerly constructed formalisms; the emotional meaning is the value we assign to mathematical speech act (an aesthetic value, a 'sportive value' etc.). 
periods: 1) the first, which lasted until the $19^{\text {th }}$ century, was characterized by the belief of the existence of properties of time and space, independent from language and logic, and was called by Brouwer (1991, p. 19) 'Kantian viewpoint':

Bis weit in das 19. Jahrhundert hinein hat man an die Existenz einer aussersprachlichen, und ausserlogischen, Mathematik der Zeit und (unabhängig davon) des Raumes geglaubt, deren Exactheit man aber jedenfalls in einem grösseren wissenschaftlichen Lehrgebäude nur so aufrechterhalten könnte, dass man einige [...] empfundene Wahrheiten sprachlich registrierte und in dieser Weise exakt festlegte und sich dann [...] mittels der vier aristotelischen Spezies ${ }^{14}$ zu einer Theorie [...] erhob.

2) The first period finished as a result of non-Euclidean geometry and the theory of relativity that ended the belief of the Kantian theory of space and allowed mathematics to be based on the theory of numbers. Therefore, the second period is characterized $(1991$, p. 20) by the arithmetization of geometry which was enhanced by the important role that was played by logic in this process (in linking the mathematical propositions):

haben die altformalistische Schule (Dedekind, Peano, Russell, Couturat, Hilbert, Zermelo) dazu ermutigt, den kantischen Standpunkt vollständig aufgeben, und bis auf einen (aussersprachlichen) Zweckmässigkeitsanlass, alles aussersprachliche und ausserlogische aus der Mathematik auszuschalten).

Meanwhile, the pre-intuitionistic school (Kronecker, Poincaré, Borel, Lebesgue) was 'ganz anders orientiert' (1991, p. 20):

Es hat für die Konstruktion der natürlichen Zahlen und das Prinzip der vollständigen Zahleninduktion den deskriptiven kantischen Standpunkt beibehalten, der eine von Sprache und Logik unabhängige Exaktheit postuliert, also der Widerspruchsfreiheit ohne logische Beweis a priori sicher ist: für die Einführung des Kontinuums hat die den Mut dazu gehabt. 'Das gegebene' mathematische Kontinuum entsprach nicht einer aussersprachlichen, mithin ausserlogischen intuitiven Konstruktion, sondern wurde auf Kosten der ausserlogischen Existenzsicherheit eingeführt [...] Weil diese präintuitionistischen Überlegungen teilweise nicht auf anschauliche Empfindung beruhen, genügen sie weder der korrektiv-kantischen noch der deskriptiv-kantischen Forderung.

Brouwer also underlined that pre-intuitionism continued to apply logic (including the principium tertii exclusi) confidently, even after the discovery of logical antinomies.

The new-formalistic school belonged to the same period and was represented by Hilbert, Bernays, Ackermann and von Neumann. At the end of this period the existence of natural numbers and the non-contradictoriness of their theory was based 'aussersprachlig'; on the contrary, a linguistic proof of non-contradictoriness of the theory of the continuum is looked for, presupposing a trust on the four Aristotelian logic principles ('Spezies'). 3) The third period was characterized by the two acts (Handlungen) of Intuitionism. The first 'Handlung' is described as follows (1991, p. 21):

\footnotetext{
${ }^{14}$ Here Brouwer meant the four logical principles. In 'Mathematik, Wissenschaft und Sprache' $(C W I$, p. 422$)$ he listed the principles one by one: the principles of identity, syllogism, contradiction, excluded third. In his thesis, in the part devoted to 'propositional functions and classes' ( $C W I$, p. 88) he stated: 'We safely apply the principles of identity, syllogism, distribution, contradiction and tertium non datur'. Therefore, he listed five principles (there was also the principle of distribution). In 1908 he named the principles of contradiction, excluded third, and syllogism: the principle of identity was missing. In the 1905 text 'Sur l'utilité de la logique algorithmique' (which is printed with this title), presented at the 1904 Philosophy Congress in Geneva, Couturat emphasized that logistics had allowed to clarify which the principles of logic were. There was, in fact, no single principle - that of identity - from which others could be deduced, but there were four principles: identity, contradiction, excluded third, and syllogism, each independent of each other and each having two senses - one related to the concepts and one related to the statements. I suppose there was an influence of this paper on Brouwer's lists of logical principles. About this question see also van Atten and Sundholm 2017, p. 26.
} 
Die rückhaltslose Loslösung der Mathematik von der mathematischen Sprache und dementsprechend von der sprachlichen Erscheinung der theoretischen Logik. Die intuitionistische Mathematik ist eine vom menschlichen Geiste vollzogen sprachlose Konstruktion die sich in restloser Exaktheit entwickelt aus der Ur-intuition der Zwei-Einigkeit.

Brouwer explained his criticism of the principle of the excluded middle and the doubts stemming from such criticism: were the 'fruchtbare, überabzählbare, fertige Spezies' of the continuum-theory to be 'deklassiert' 'zu einem inextakten Ausläufer der beschreibende Naturwissenschaften?' (1991, p. 23). In particular, it was based on logic, which was no longer trustable. The answer came from the second 'Handlung', consisting in the self-exploiting of the 'Ur-intuition'. The book was committed in explaining that Handlung.

Brouwer maintained the two labels that he had already introduced (formalism vs intuitionism), by adding a Kantian viewpoint that in the 1912 lecture simply belonged to 'intuitionism' and that in his final works will disappear. Furthermore, he distinguished two standpoints in each label: an old (or pre-) and a new one. As van Dalen remarked (1991, p. 9), in his works before 1927, Brouwer defines his own intuitionism as 'neointuitionism'. This label was present also in the first draft of the lessons, but the prefix 'neo' was cancelled by the author. In Brouwer's later papers his intuitionism will always be called 'intuitionism', while Poincaré and Borel's viewpoint will be considered as 'pre-intuitionist'. Van Dalen stressed that a good amount of selfconsciousness was already present in Brouwer's early scientific years in the choice of a label ('newintuitionism') that defined the position of only one person in the world. Nevertheless, in 1927 Brouwer's 'selfconsciousness' had become greater. In particular, he used 'intuitionism' for his opinion and 'pre-intuitionism' for the French school: by doing so Brouwer could highlight that his intuitionism was the end point of a finalized path, and not a variant of an already existing school.

\section{Brouwer in $\mathbf{1 9 2 8}$}

1928 was an abundant year for Brouwer's works. He published the paper 'Intuitionistische Betrachtungen über den Formalismus' and held two lectures in Vienna (published resp. one and two years lately).

\section{1. 'Intuitionistische Betrachtungen über den Formalismus'}

In his 1928 'Intuitionistische Betrachtungen über den Formalismus' Brouwer went on with his 'duel' against formalism and listed four viewpoints that the intuitionists asserted and that he was sure that, sooner or later, also formalists would share: this would mark the end of the 'Grundlagenstreit' and from that time on, the choice between formalism and intuitionism would only be 'a question of taste'. The four viewpoints mentioned were:

1) The formalists' aim to build a formal image of mathematics while they also have an intuitive theory of the laws of such a construction. Namely, they admit that intuitionistic mathematics of the integers is indispensable for their intuitive theory.

2) The refusal of a blind application of the principle of the excluded middle, which has a sure validity only for finite domains.

3) The identification of the principle of the excluded middle with the principle of the solvability of every mathematical problem.

4) The knowledge that justifying formalistic mathematics through the proof of its non-contradictoriness contains a vicious circle: it is founded on the law that allows to move from the double negation to the affirmation; but this law is based, at its turn, on the principle of excluded middle.

Before giving counterexamples to the principle of the excluded middle (interpreted intuitionistically), Brouwer stressed that formalists had not concluded anything as far as the certainty of mathematics was concerned, while intuitionists had a sound basis for their mathematics. 


\section{2. 'Mathematik, Wissenschaft und Sprache'}

In 'Mathematik, Wissenschaft und Sprache', Brouwer pointed out the difference between pure mathematics (developed out of the intuition of the duo-unity) and the mathematical observation of the world (i.e. the application of mathematics to the sensible world); then, he mentioned the language that comes after the mathematical construction (it cannot be used to develop mathematics itself). He mentioned the formalistic school (CWI, p. 422) and declared that its fault resided in its belief in classical logic. The origin of such belief consisted in the fact that their laws were trustable when they were referred to finite domains. But this trustworthiness led men to a superstitious faith in the miraculous power of language: there was no need of checking whether there was a reality corresponding to an assert logically derived from some axioms. Their derivability was itself a warranty of existence. Among philosophers this attitude led them to consider as 'ideal truths' concepts that contradicted the perceptual data. If some doubts about the deduction leading to such falsities were risen, then a modification of axioms was proposed: logical laws were never touched. Mathematicians did the same: they applied logical laws to infinite domains without hesitations and produced ideal truths 'welche von den Mathematikern mehr als leere Worte gehalten wurden' (CWI, p. 424). When they crashed against the contradictions produced by an unlimited application of the axiom of comprehension, at first they tried to re-arrange the axioms and, when that failed, they tried 'widerspruchsfreie Neugestaltung der mathematischen Sprache' that required only limited 'Amputationen' in mathematics. Here the intuitionists contrasted the formalists once again: intuitionists destroyed confidence in logical laws when applied to infinite domains by giving counterexamples to the validity of the principle of the excluded middle in those domains and criticized formalists for building a linguistic castle instead of a mathematical building.

\section{3. 'Die Struktur des Kontinuums'}

'Die Struktur des Kontinuums' was devoted to explaining the novelty of Brouwer's work of the continuum through the exploitation of the duo-unity in terms of lawless sequences. In order to do this, Brouwer pointed out the different approaches to the continuum in recent history of mathematics. The partition among schools was expressed as follows: his opinion was called 'intuitionist'; then there were formalists (stemming from Dedekind, Peano, Russell, Zermelo and Hilbert) who only paid attention to mathematical language and avoiding the production of contradictions in the theorization of the continuum; and old-intuitionists (stemming from Poincaré and Borel) for whom only the denumerable part of the continuum had a content, i.e. could be built by constructive means starting from the intuition of the duo-unity, while for the more-than-denumerable continuum the reference to a linguistic source is necessary.

In 1928 Brouwer had a terrible argument with Hilbert, described in van Dalen 1990. Hilbert re-founded the Mathematische Annalen to cast him off the editorial committee. Although the other editors tried swallow the bitter pill, Brouwer felt very hurt. From 1930 to 1948, he stopped his publications, except for a few minor ones.

\section{Logicism as a label at the horizon: its philosophical precursors (Wundt, Groos, Ziehen, Clausberg and Dubislav)}

Before being part of the literature of foundations of mathematics, the term logicism appeared, in different occasions, in philosophical texts at the beginning of the $20^{\text {th }}$ century by Wilhelm Wundt, Karl Groos, Theodor Ziehen, Johannes Clausberg and Walter Dubislav. 


\subsection{Wilhelm Wundt}

The term 'Logizismus' appeared in 1910 in Wundt 'Psychologismus und Logizismus'. He stated that the two terms were new with respect to the intended use. They represented two views about philosophy, and in this sense they were as old as philosophy itself: ${ }^{15}$

Versteht man unter Psychologismus diejenige Tendenz in der Philosophie der Gegenwart und der jüngsten Vergangenheit, die in der psychologischen Analyse des Inhalts der Erfahrung die wesentliche Aufgabe der Philosophie erschöpft sieht, so ist es klar, daß er nur einen Versuch darstellt, die gesamte Philosophie und damit die Wissenschaft überhaupt auf die reine Erfahrung, wie sie in den unmittelbaren Tatsachen unseres Bewußtsein enthalten ist, zurückzuführen. Im Gegensatz dazu würde dann der Logizismus der Versuch sein, umgekehrt, auf dem Weg der logischen Reflexion über den Zusammenhang der Erscheinungen, insbesondere auch derer, die uns im eigenen Bewußtsein gegeben sind, Rechenschaft abzulegen [...] Der eine dieser Standpunkte ist der deskriptive, der andere der explikative. Beide widerstreiten sich nicht, sondern sie verbinden sich in dem Sinne, daß zunächst eine beschreibende Analyse die genaue Kenntnis der Tatsachen zu vermitteln pflegt, ehe eine Interpretation ihres Zusammenhangs oder, nach der üblichen Bezeichnung, eine 'Erklärung' stattfinden kann.

\subsection{Karl Groos}

In 1912 Karl Groos, analysed some forms of dualism in philosophy and their solutions, he saw in Cohen's statement: 'Die Empfindung ist letzlich nichts anderes als eine Fragezeichen' (1912, p. 270) a certain approach to a radical logicism. Furthermore, when presenting two methods to analyse the knowledge (das Wissen), he pointed out 'eine psychologische Betrachtung' contraposing to 'eine logische Betrachtung' (1912, p. 270):

Die Methoden des Psychologen haben es mit den realen, zeitlich fließenden Bewußtseinsinhalten des erlebenden Individuums zu tun [...] Der Logiker löst seine Gegenstände von dem Konnex mit dem erlebenden Subjekt ab und verwandelt sie in ideale Gebilde, die der Zeit enthoben sind.

Finally, he defined 'naiven Logizismus' that 'der sich den logischen Gegenständen gegenüber genau so unkritisch verhält wie der naive Realismus den Naturobjekte gegenüber’ (1912, p. 271).

\subsection{Theodor Ziehen}

In 1914 Theodor Ziehen, who had inherited the label 'Logismus' for Edmund Husserl's anti-psychologistic logic ${ }^{16}$ from Ludwig Busse, ${ }^{17}$ changed $^{18}$ it into 'Logizismus' by defining it as follows (1914, pp. 30-37):

\footnotetext{
15 (http://www.gleichsatz.de/b-u-t/begin/wundt/wu-psylog1.html).

16 As he himself mentioned (1920 p. 173n) in a kind of history of the word 'Logizismus', François Viète used 'logistic' for Rechenkunst and algebra ('Logistice numerosa est quae per numeros, speciose quae per species seu rerum formas exhibetur, ut pote per alphabetica elementa' - Viète 1691, p. 5). Later, Wilhelm Traugott Krug used it for Rechenkunst and Syllogism ('Logistik ist eigentlich Rechenkunst. Doch wird es auch zuweilen fuer Syllogistik oder Schlußkunst

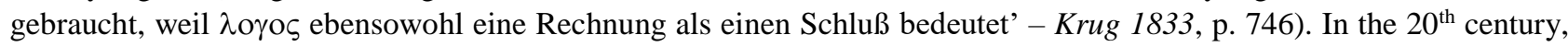
Louis Couturat (with Itelson and Lalande, as reported in his 1905 recollection of the international congress of philosophy) and Alexius Meinong ("symbolischen Logik", fuer die sich der Name "Logistik" mit Recht durchzusetzen scheint' Meinong 1907, p. 115), restricted the term 'logistic' to indicate 'algebra of logic'. L. Busse used the term 'Logismus' for Edmund Husserl's anti-psychologistic logic in a 1903 review of the Logische Untersuchungen (1903, p. 153):

In dieser Hinsicht ist nun vor allem hervorzuheben Husserls Abschwenken vom Psychologismus, den er in seiner Philosophie der Arithmetik vertreten hatte, zu einem Standpunkte, den man als Logismus oder als transzendentalphilosophischen bezeichnen kann.

Ziehen mentioned Wundt in other parts of the book for other purposes, but he did not quote Wundt on this purpose (see Peckhaus' remark: at http://www.rbjones.com/rbjpub/philos/glossary/logicism.htm).

${ }^{17}$ See Ziehen 1913, p. 411.

${ }^{18}$ He specified: 'Die Bezeichnung "Logizismus" statt "Logismus" schließt Verwechslungen noch sicherer aus' (1914, p. 31). In 1920 (p. 173 n) he stressed that he had changed the label because 'Logistik' had been used in France for a long time to mean algebraic logic. In the same place he mentioned Groos' use of 'Logizismus' as follows: 'Auch K. Groos verwendet die Bezeichnung "Logizismus" ähnlich wie ich'. It seems that Ziehen wanted to attach himself the priority at least for the autonomy in choosing such label.
} 
Zwei Richtungen der Erkenntnistheorie sind es namentlich, die in diesem Sinn den rekonstruierenden Standpunkt von der Empfindungswelt ganz oder fast ganz loslösen, eine ältere, die man gewöhnlich als Rationalismus bezeichnet, und eine neuere, die jener nahe verwandt ist, aber doch in der übertriebenen Hervorhebung des logischen Standpunktes von ihr abweicht und im Hinblick auf diese Eigentümlichkeit als Logizismus bezeichnet werden kann. [...] Für den Logizisten sind die logischen Begriffe und Urteile nicht ein kleiner Teil des Gegebenen, dem nur die Bedeutung der Zusammenfassung von anderem Gegebenen zukommt, wie von der genetischen Erkenntnistheorie gelehrt wird, sondern sie haben wenigstens zum Teil - eine Stellung ausserhalb des Gegebenen und über dem Gegebenen.

In 1920 he kept the word 'logicism' from an epistemological viewpoint (among other, independent, five ones), opposed to the 'psychologisch-sensualistisch-induktive Richtung'. According to him, logicism affirmed the existence of a 'rein Logisches' in addition to the Tatbestand and to the Denkergebnis (1920, p. 172):

der Satz, daß außer den Empfindungen und den aus ihnen hervorgegangenen Vorstellungen [...] als Grundlage anzunehmenden Dingen an sich das Logische in irgendeiner Weise eine eigene, selbstständige Existenz hat, also gewissermaßen neben den psychischen Vorgängen der Empfindungen, der Vorstellungen und des Denkens und neben den Dingen an sich [...] ein drittes Sein darstellt.

The authors Husserl and Bolzano were contemplated. Furthermore, also Windelband and Rickert as the representatives of a so-called 'Werttheoretischer Logizismus' ${ }^{19}$ Finally, Lotze and Teichmüller are labelled as 'semi-logicists', because both of them affirmed the existence of 'das Logische', but they didn't explain how. Ziehen also expressed his opinion about logicism. He stated that it had started from a right idea, i.e. the distinction between logic and psychology that is to say that logic looked for the correct thought and not for its effective development. Still, logicism was wrong because it separated logic and psychology and 'das Logische' was seen as a third domain: '[...] das Logische ganz vom Psychologischen loslöst und als ein ganz besonderes Reich deutet, das ebensowohl von den Dingen (Dingen an sich usw.) wie von den psychischen Vorgängen ganz unabhängig ist' (1920, p. 258). ${ }^{20}$ As for Frege and Russell, Ziehen mentioned them with the label 'Mathematical logic' and saw a link with logicism only for the fact that 'some logicists' considered the general set theory as a part of pure logic $\left(1920\right.$, p. 228). ${ }^{21}$

\subsection{Johannes Clausberg and Walter Dubislav}

In 1923 the Wörterbuch mentioned above was published by Clausberg and Dubislav. We have already seen that they presented the label 'Intuitionismus'. Our attention must be focused on the other label they introduced, i.e. 'logicism'. The first entry in which the label appeared was 'ethics', as a kind of answer to the question about the essence of ethical norms (1923, p. 161): 'Eine Lehre der Ethik heißt eine 'logizistische', der zufolge

\footnotetext{
${ }^{19}$ In particular, Rickert was seen near to logicism because he considered as distinguished the two worlds called resp. 'Welt der seienden' and 'Welt der geltenden' (that the subject keep linked though his judgements). Still, logic is this second world, therefore 'das Logische existiert nicht, sondern es gilt' (Ziehen 1920, p. 190).

${ }^{20}$ Ziehen stressed the following aspects: 1) it is impossible to obtain 'materiale Aufschlüsse', independent from experience, through a mere analysis ('Zergliederung') of a concept (for instance, it is impossible to get to synthetic a priori knowledges through the analysis of the concept of 'experience'); 2) it is useless to add a 'third' ('das Logische') to individual perceptions and to the things in themselves. It remains undefined and without examples. Even logicists do not agree with the 'Seinsweise' of logical objects; 3) the complete separation of das Logische from das Psychische is never complete. The logicist believes that this is possible only because he confuses das Psychische and das Psychologische (1920, p. 262).

${ }^{21}$ In 1914 , p. 38 he wrote:

Die mathematische Mannigfaltigkeitslehre, die von den Logizisten gern als Beispiel einer 'rein-logischen' Leistung angeführt wird, ist durchaus keine reine Logik. Soweit sie mehr ist als blosse Zeichenlehre und formale Logik, soweit sie also nicht lediglich gewisse Worte und Zeichen im Interesse eines eindeutigen und konstanten Gebrauchs definiert und die sich aus diesen Definitionen ergebenden formal-logischen Konsequenzen zieht, ist sie nichts anderes als Mathematik und wie diese auf Erfahrung gegründet.

It is clear that Ziehen used the label 'Logicism' as a general approach to the theory of knowledge (and not as a specific foundational label for mathematics. At most, according to him, some part of mathematics could be used as an example of pure 'apriori' by philosophers who liked a logistic methodological approach to knowledge).
} 
die Widerspruchslosigkeit der Beweggründe des Wollens hinreichende Bedingung für die Sittlichkeit des Wollens ist'.

The second entry was 'Logik, Mathematik'. Its first meaning was (1923, p. 275):

Diejenige Wissenschaft, welche darin besteht daß aus einer Gesamtheit als denknotwendig zu bezeichnender Sätze sämtliche andere als denknotwendig zu bezeichnenden Sätze begründet bzw. zu begründen versucht werden, so wie es in der betreffenden Gesamtheit enthaltene Sätze angeben.

They specified that 'logistic', 'mathematical logic' and 'algebraic logic' were synonyms of what refers to the first meaning of logic. In connection with this meaning, the authors inserted 'mathematics' as the 'totality' of 'pure mathematics' and 'applied mathematics'. Finally, they specified that it was possible to consider logic as either dependent on or independent from psychology, the theory of knowledge and metaphysics. If one believed that logic was presupposed by all the other sciences, then his/her viewpoint had to be called 'logizistische'22 (1923, 276).

Then in 1926 Dubislav $^{23}$ (alone) presented a tripartite relationship between logic and mathematics referring to Russell's viewpoint (mathematics was completely reducible to logic), Brouwer's viewpoint (logic was based on mathematics) and Hilbert's viewpoint (logic was independent but mathematics used logical rules in its theorems), but without labelling them. In the first issue of Erkenntnis, Dubislav published his 'Über den sogenannten Gegenstand der Mathematik', where he pointed out four 'Grundansichten': '1) die PlatonKantschen These zuzüglich der intuitionistischen; 2) die empirische These; 3) die konventionalistische These; 4) die formalistische These wie deren Vorläuferin, die logizistische' (1930, p. 27). In the first viewpoint, he also dealt with Brouwerian intuitionism, by mentioning the author's distinction between an old and a new intuitionism (1930, p. 33). Dubislav saw a common element between all intuitionisms: 'Ur-intuition' as the basis of mathematics. He described formalism (1930, p. 41) as the statement that mathematics and logic are not sciences ('Wissenschaften') but calculations ('Kalküle') where one could derive, from arbitrary initial formulas, other formulas according to certain arbitrary rules of operation. And in the footnote (1930, p. 41) he referred to logicism, by distinguishing between 'der ältere Logizismus' - represented by Russell - which affirmed that mathematics could be restlos reduced to logic and consisted of a system of analytic truths; and 'der neuere Logizismus' - represented by Wittgenstein - which affirmed that mathematics and logic were systems of tautologies (i.e. judgements true and a priori) and have nothing to do with reality: 'Sie sind also keine Bilder der Wirklichkeit, sondern vielmehr bedingungslos wahre Aussagen' (1930, p. 41). This viewpoint is confirmed in his 1931 paper and in the 1932 booklet (see also Allen 1933), even though logicism is no longer presented as a precursor of formalism. ${ }^{24}$

\section{Logicism as a label in foundations of mathematics: Fraenkel and Carnap}

In the years 1928-1931 the label 'logicism' also appeared in the foundations of mathematics thanks to Abraham Fraenkel and Rudolf Carnap.

\footnotetext{
${ }^{22}$ They considered the Kantian definition of logic as 'Die Wissenschaft von der Verstandesregeln' as the second meaning of logic, and Überweg's definition ('Logik as Wissenschaft von den normalen Gesetzen der menschlichen Erkenntnis') as a third meaning of the word. The fourth was according to Sigwart ('Kunstlehre des Denkens, welche die Kriterien des Wahren Denkens bestimmen soll'); the fifth was according to Erdmann ('Wissenschaft von der formalen Voraussetzungen des wissenschaftlichen Denkens'); the sixth was according to Wundt ('soll diejenige Gesetze des Denkens festzustellen, die beider wissenschftlichen Erkenntnis wirksam sind'); the last came from Cohen ('Lehre vom Denken, welche an sich Lehre von der Erkenntnis ist') (1923, p. 279).

${ }^{23}$ About Dubislav see Milkov 2015 and 2016.

${ }^{24}$ Formalism was his favourite viewpoint both in the philosophy of mathematics and in the philosophy of science: according to him, not only logic and mathematics were calculi, but also scientific theories were calculi with attached rules of interpretations (on this issue see Van Zantwijk 2013, Milkhov 2015 and 2016).
} 


\subsection{Abraham Fraenkel}

In 1928, in his revised edition of Einleitung in die Mengenlehre, Abraham Fraenkel distinguished three Begründungsarten of Set Theory: Logicismus, Intuitionismus and Formalismus, by specifying that he preferred logicismus. Although he assigned intuitionism the merit for pointing out 'Lücken' in the foundations of Analysis and Set Theory, Brouwer's concept of construction seemed too unclear ${ }^{25}$ for him and he was willing to give up classical mathematics only because it showed some misconduct in some of its margins. As for formalism, he didn't believe that such program could succeed, because the value of 'signs' didn't seem so crucial in mathematics (1928, p. 383). Furthermore, even if the program were to be successful, and even if its focus was only on signs, he didn't see enough of a reason to define a certain system of axioms to mathematics (instead of another), and he didn't understand how the applicability of such axioms to nature could be possible: 'Der Formalismus hat so zwischen der Mathematik und der Welt eine Kluft hervorgebracht, deren Überbrückung kaum mehr vorstellbar erscheint' (1928, p. 384). His preference for the logicism in the sense of 'Einfügung der Mathematik in den weiteren Rahmen der Logik' was not only due to the will that the difficulties linked to the reducibility axiom could be solved, but 'selbst wenn sie es nicht sein sollen', insofar as the other schools were not successful too, he could count this as proof of the limits of human thought regarding such questions $(1928$, p. 384):

So kann das, solange nicht von anderer Einstellung her ein voller Erfolg zu verzeichnen ist, ebensowohl den Schranken des menschlichen Denkens zur Last gelegt warden, über die das hier vorliegende Problem hinausgehen mag, wie etwa der Falschheit oder Unzweckmäßigkeit der logizistischen Einstellung.

He appreciated the use of axiomatic method in logicism. He stressed that the three foundations were not 'scharf voneinander geschieden', but it was possible to put them in a neat list 'durch eine Reihe möglicher und auch tatsächlich vorkommender Übergangsstufen miteinander verknüpft' and they were not exhaustive: a fourth school could be introduced or re-claimed from an old, relinquished perspective. A conciliation among the schools was impossible at his days. ${ }^{26}$ Fraenkel separated 'logistics' and 'logicismus'. He stressed (1928, p. 263 ) that the first label was not univocal, because it was used in literature to indicate the formal aspects of the new logic that had been developed in the $19^{\text {th }}$ century (algebra of logic, symbolic logic, etc.) and used for the foundational point of view. Therefore, he believed that it was better to indicate the foundational school through a specific label: 'Logizismus'. ${ }^{27}$

\subsection{Rudolf Carnap}

In 1929, in his Abriß der Logistik mit besonderem Rücksichtigung der Relationstheorie und ihrer Anwendungen, ${ }^{28}$ Carnap introduced 'Logistik oder symbolische Logik' by stressing that the whole mathematics was a branch of it. In a footnote (p. 2) he listed Ziehen (his 1920 footnote on p. 173), Meinong (the same quote reported by Ziehen) and the three scholars of the Geneva 1904 symposium ${ }^{29}$ (Couturat, Itelson, Lalande) as those who had proposed the label. Then ${ }^{30}$ he specified $(1929$, p. 3) that: 'Eine philosophische Richtung mit starker oder etwa übermässiger Betonung des logischen Gesichtspunktes nennt man nicht "logistisch" sondern besser, wie zuweilen schon üblich, "logizistisch", "Logizismus"”.

\footnotetext{
${ }^{25}$ About the relationship Fraenkel-Brouwer see van Dalen 2000.

${ }^{26}$ He quoted the same Poincaré statement that Brouwer had put at the end of his 1912 paper (mentioned above).

${ }^{27}$ In order to support his remark about the equivocal terminology, he quoted (1928, p. 263) Ziehen (1920, p. 173) and Lewis (1918). Charles Irving Lewis presented two different definitions of logistics: an orthodox one and a heterodox one. The orthodox view considered logistic as a name for abstract mathematics, developing through logical operations represented in the ideographic symbols of symbolic logic $(1918$, p. 343). The heterodox view considered symbolic logic as one inferential system ('type of order') among other possible ones, and logistic as the study of the various types of order (1918, pp. 354-55).

${ }^{28}$ About this book see Grattan-Guinness 2000, pp. 500-502.

${ }^{29}$ About the Geneva Congress see Grattan-Guinness 2000, pp. 366-368.

${ }^{30}$ He didn't quote Fraenkel, but Lewis (1918, p. 340), where he had proposed to restrict the use of 'logistic' to the method of applying symbolic logic to 'außerlogischen Gebieten' (Carnap 1929, p. 2).
} 
Thus, in 1929, he seemed to use 'Logizismus' more in a general philosophical sense than with a mathematicalfoundational meaning. Also the following year, in the first issue of the journal Erkenntnis (1930, p. 12) he introduced $^{31}$ the new method of doing philosophy as a logical analysis of the concepts referring to what he would later call 'logicism' but without using that label. Only in 1931 Carnap introduced, in the proceedings of the Königsberg Colloquium, published in the second volume of Erkenntnis, three different foundational schools that he labelled resp. as logicism, intuitionism and formalism. The aim of the congress was to make a budget of their situation at the beginning of the Thirties. The school that he represented was logicism and he pointed out the relationship between mathematics and logic as one of the most intriguing matters concerning the problem of foundations. He stated that logicism saw mathematics as a part of logic so that mathematical concepts were deducible from logical concepts and mathematical theorems were provable starting from logical asserts (1931, p. 94):

Das wesentliche an der angedeuteten Methode der Einführung der reellen Zahlen ist, da $\beta$ hier diese Zahlen nicht 'postuliert', sondern 'konstruiert' werden. Es wird nicht durch Postulate oder Axiome die Existenz von Gebilden angesetzt, die die Eigenschaften der reellen Zahlen haben, sondern es werden durch explizite Definitionen logische Gebilde konstruiert, die auf Grund dieser Definitionen diejenigen Eigenschaften haben, die man in der Arithmetik den reellen Zahlen beizulegen pflegt. Eine Begriffsbildung ist nicht eine Erschaffung, sondern nur eine Namengebung für etwas, das als vorhanden schon nachgewiesen sein muß; es gibt keine 'schöpferischen Definitionen'.

Carnap saw the very problem of logicism in the will of avoiding both the axiom of reducibility and the division of real numbers into different orders. Then, he also looked for similarities among the various schools. ${ }^{32}$ The similarity between logicism and intuitionism consisted in the fact that for both of them no concept could only be built on the axiomatic basis. Concepts had to be constructed out of undefined basic properties of a given domain according to some rules of constructions in a finite number of steps. The similarity between logicists and formalists consisted in the fact that during the deduction in both cases no reference to the meaning of the words was considered.

\section{Brouwer: the final solution}

We have seen that in his 1927 Berliner lectures Brouwer had introduced the difference between old formalism and new formalism. One could expect that in 1931 he could have used Gödel's results as a weapon against formalists, but he did not. On this purpose, Hao Wang reported (1987, p. 88):

In the spring of 1961 I visited Brouwer at his home. He discoursed widely on many subjects. Among other things he said that he did not think Gödel's incompleteness results are as important as Heyting's formalization of intuitionistic reasoning, because to him Gödel's results are obvious (obviously true).

Van Atten 2017 (Sect. 3.5) observed that Brouwer's reaction to the first incompleteness theorem was understandable. Undeniably, it had been Brouwer's argument that had stimulated Gödel in finding the first theorem. As reported in Carnap's diary note on December 12, 1929, he stated that Gödel spoke about the

\footnotetext{
${ }^{31} \mathrm{He}$ added that the new logic, which had its first attempts with Frege, Peano and Schröder, and had been well developed by Whitehead and Russell, was essential for this aim: the old one, that was centered around the structure subject-predicate could not allow a refined analysis of all concepts because it neglected relations (larger than, near to, etc.) (and in this way it supported metaphysical monsters like an absolute subject to which everything would belong as an attribute). Here Carnap recalled that the new logic, which had been further modified after the discovery of logical antinomies, allowed to obtain all of mathematics out of logical concepts. So, he referred to logicism without using that label.

${ }^{32} \mathrm{He}$ worked to find a synthesis of logicism and formalism (see Oberdan 1993).
} 
inexhaustibility of mathematics and declared to have been stimulate ${ }^{33}$ into this idea during Brouwer's lecture in Vienna on that day. ${ }^{34}$ In an alleged paper, Carnap wrote (Wang 1987, p. 50) what Gödel told him:

We admit as legitimate mathematics certain reflections on the grammar of a language that concerns the empirical. If one seeks to formalize such a mathematics, then with each formalization there are problems, which one can understand and express in ordinary language, but cannot express in the given formalized language. It follows (Brouwer) that mathematics is inexhaustible: one must always again draw afresh from the 'fountain of intuition'. There is, therefore, no characteristica universalis for the whole mathematics, and no decision procedure for the whole mathematics. In each and every closed language there are only countably many expressions. The continuum appears only in 'the whole of mathematics' [...] If we have only one language, and can only make 'elucidations' about it, then these elucidations are inexhaustible, they always require some new intuition again.

According to van Atten 2017, the second incompleteness theorem, on the other hand, must have surprised Brouwer, given his 'optimism' in the 1920s about the formalist school achieving its aim of proving the consistency of formalized classical mathematics. Such optimism appeared in a paper full of counterexamples where he described (Brouwer 1924, p. 3, CW I, p. 270):

We need by no means despair of reaching this goal (of a consistency proof for formalized mathematics), but nothing of mathematical value will thus be gained: an incorrect theory, even if it cannot be inhibited by any contradiction that would refute it, is none the less incorrect, just as a criminal policy is none the less criminal even if it cannot be inhibited by any court that would curb it.

Brouwer alluded ${ }^{35}$ to Gödel's results both in his Cambridge Lectures and in his 1952 paper 'Historical Background, Principles and Methods of Intuitionism', by stating (Brouwer 1952, p. 508):

The hope originally fostered by the Old Formalists that mathematical science erected according to their principles would be crowned one day with a proof of non-contradictority, was never fulfilled, and, nowadays, in view of the results of certain investigations of the last few decades, has, I think, been relinquished.

Yet, Brouwer did not stress the surprising result in order to support his own opinion. I suppose that, since he had previously attached no value to the achievement of a consistency proof, the impossibility of achieving it however did not appear to him as a relevant point in his argumentation against formalism: the impossibility of achieving something useless must have not been particularly interesting for him. By reconsidering the history of foundational viewpoints he introduced an evolution of an old period of intuitionism (called 'observational period' - instead of 'Kantian period'), and he asserted that the new formalist school, founded by Hilbert, came out when the old formalist standpoint 'had been badly shaken' by the criticism of pre-intuitionists. They stressed out the essential difference between logic and mathematics and an autonomy of the so-called separable parts of mathematics from the rest. In his new formalism, Hilbert made use of the intuition of natural numbers and of complete induction, and postulated the existence and exactness independent from language only for meta-mathematics. Brouwer posed the intervention of (his) intuitionism here, after Hilbert's new-formalism, and depicted the situation 'after' Hilbert's viewpoint in this way (CW I, p. 509):

The situation left by Formalism and Pre-intuitionism can be summarized as follows: for the elementary theory of natural numbers, the principle of complete induction, and more or less considerable parts of algebra and theory of numbers, exact existence, absolute reliability, and non-contradictory were universally acknowledged, independently of language and without proof. There was little concern over

\footnotetext{
${ }_{33}$ Yet, van Atten and Kennedy 2009, p. 499 stressed that in his theorem, even though inspired by Brouwer, Gödel went considerably beyond Brouwer because he gave statements expressible within the axiom system but which may not be decided from the axioms.

${ }^{34}$ About the personal contacts between Brouwer and Gödel see also van Atten and Kennedy 2009, pp. 501-503 and van Atten 2015, pp. 165-171, 190-191.

35 On this purpose, van Atten and Kennedy 2009 (p. 499) affirmed: 'Brouwer never explicitly commented on Gödel's theorems in print, but clearly had the (second) incompleteness theorem in mind when he wrote his 1952 paper'.
} 
the existence of the continuum. Introduction of a set of pre-determinate real numbers with a positive measure was attempted by logico-linguistic means, but a proof of the non-contradictory existence of such a set was lacking. For the whole of mathematics the rules of classical logic were accepted as reliable aids in the search for exact truths.

In this situation, his intuitionism intervened through his two famous acts. In the first, he separated mathematics and logic, and based mathematics on the languageless activity of mind having its origin in the perception of time. In the second he recognized the possibility of producing: 1) the infinitely proceeding sequences of mathematical entities (previously acquired); 2) mathematical species, i.e. properties supposable for mathematical entities previously acquired. ${ }^{36}$ Then, Brouwer described the main results of his theory of the continuum (for instance, his fan theorem), and he did not add anything else about the other schools.

We have seen that Brouwer presented the point of view of 'Cantorians', 'axiomaticians' and 'logistics' and confronted his perspective (not yet labelled) with each of them in his dissertation (1907). From the 1911 review of the Mannoury volume Methodologisches und Philosophisches zur Elementar-Mathematik Brouwer introduced the foundational scene of the last century and divided it into two main parts: the 'formalists' (including Dedekind, Peano, Russell, Hilbert and Zermelo) and the 'intuitionists' (represented by Poincaré and Borel). The following year, Brouwer chose the label 'neo-intuitionism' for his foundational school, and maintained the label 'formalism' to indicate all the others. In the 1930 Königsberg conference ${ }^{37}$ (attended by Carnap, Heyting and von Neumann), the label 'formalism' was used for the Hilbert school, while the label 'logicism', which appeared (in the foundational context) two years before in the revised edition of the book Einleitung in die Mengenlehre by A. Fraenkel, was attributed to the school of Frege-Russell (represented at the conference by Carnap). Brouwer didn't share such a tripartition, and in his later writings he settled on the contrast intuitionism-formalism, as given in his 1927 Berliner lectures, where he distinguished two schools: Dedekind and Zermelo were old formalists, Hilbert was a new formalist; Poincaré and Lebesgue were preintuitionists, Brouwer himself was an intuitionist. My explanation is that Brouwer, as a founding father, wanted to present himself as new and definitive hence he used two labels in order to describe the entire matter as it could only be divided into 'self' and 'non-self': it was a way to focus-on his own perspective and to reaffirm its trait of absoluteness.

\section{Arend Heyting}

Arend Heyting was Brouwer's pupil, he got his $\mathrm{PhD}$ in 1925 with the thesis Intuitionistische Axiomatiek der Projectieve Meetkunde (Intuitionistic Axiomatics of Projective Geometry) and took part in the Königsberg conference in 1930 as the representative of intuitionism.

\subsection{Mathematische Grundlagenforschung. Intuitionismus. Beweistheorie}

In his 1934 Mathematische Grundlagenforschung. Intuitionismus Beweistheorie, he showed that he had acknowledged the tri-partition of the foundational schools. In particular, at the beginning of the book he stressed that three main directions had been designed (gebildet) in the foundations of mathematics: the formalist, the intuitionist and 'die logistische Auffassung' (1934, p. 1), and described metamathematics as a byproduct of logistic, in which formalists were also interested in (1934, pp. 4-5):

Nach der logistischen Auffassung ist die Mathematik ein Zweig der Logik. Es entstanden so die mathematische Probleme, erstens die Logik exakt aufzubauen, zweitens die Mathematik aus der Logik wirklich zu entwickeln. An diesen formalen Aufbau schießen sich dann die 'metamathematischen' Untersuchungen an, in denen der formale Apparat an sich, ohne Rücksicht auf seine inhaltliche Bedeutung, auf seine Struktur untersucht wird. Gerade diese metamathematischen Untersuchungen

\footnotetext{
${ }^{36}$ And satisfying the conditions for identity: if they hold for a certain mathematical entity, they should also hold for all mathematical entities which have been defined to be equal to it, relations of equality having to be symmetric, reflexive and transitive.

${ }^{37}$ About the 1930 conference see Grattan-Guinness 2000, pp. 508-509.
} 
fangen an, sich zu selbstständigen Disziplinen zu entwickeln. Nach formalistischer Auffassung ist die eigentliche Mathematik rein formaler Art; es wird aber großer Gewicht gelegt auf die metamathematische Betrachtung der formalen Mathematik, durch die insbesondere die Widerspruchsfreiheit [...] des formalen Systems sichergestellt werden soll.

He did not go into detail in 'die logistische Aufbau', because it was Gödel that was in charge of that part of the book. At the end Gödel delays so much that publisher and co-author decided to give up his part (see Parsons 2003 , pp. 28-33). The plan of the book ${ }^{38}$ that Heyting proposed in his first letter was the following (Gödel 2003, p. 35):

1. Short historical introduction. (Poincaré); 2. The paradoxes; attempts at resolution apart from the three principal directions; 3. The calculus of logic; its further development (Americans); logicism; 4. Intuitionism; 5. Formalism; 6. Other standpoints; 7. Relations between the different directions; 8. Mathematical and natural science.

Gödel should have covered the first three chapters, but he tried to re-adjust the distribution. In a draft of a letter (VIII 1931) he explained that metamathematics was hardly separable from logistic ('Logistik') because metamathematics was a theory of the linguistic forms: so he suggested to keep that part for himself, by leaving Heyting the formalization of intuitionism (in addition to intuitionism and semi-intuitionism). Later (IX 1931), he proposed to deal with metamathematics as an adjoint part to logicism by himself again; in another chapter, one of them should have delt with the foundations of formalism (in particular the consistency of the calculus). In June 1932 (letter 4), Heyting asked Gödel to write a part on metamathematics: they would have later decided whether to insert it in the chapter about logicism ${ }^{39}$ or, better, in the one about formalism. In any case, he left Gödel a great deal of Poincaré's criticisms in general, and also suggested to grant him a separate chapter, because Poincaré's criticisms concerned many foundational viewpoints. He himself didn't want to write that part because he felt he didn't have enough knowledge of Poincaré's historical background. In letter 5 (also written in june 1932), Heyting stated that there were works that delt with formal logic 'without philosophical presuppositions', for instance American investigations about axiomatics of Boolean algebra, the works of Bernays and Schönfinkel, the works about the Entscheidunsproblem, and Hilbert's 'Theoretische Logik'. He suggested to put them 'im Anschluss an dem Logizismus'; he also left Gödel the presentation of Chwistek (either among the logisticians or in the chapter that collected all other viewpoints) and the relationship between logicism and natural sciences (to be inserted in the final chapter). In fact, Gödel did not send his part. Heyting took care of the part devoted to both 'intuitionism'40 and 'formalism' (named in the title of the book: 'Beweistheorie') and wrote other two parts about 'Andere Standpunkte' and 'Mathematik und Naturwissenschaft'. In 'Andere Standpunkte' he affirmed that never had two mathematicians fully agreed about that subject; furthermore, at that point in time many philosophers showed interest in foundational items. Therefore, a lot of foundational nuances could be listed, and, even if they could be discussed in all of the book, the author could not discuss them 'weil die Argumente eines Philosophen meistens erst in dem Zusammenhang seines Systems verständlich sind' (1934, p.67). Consequently, he briefly quoted Otto Ludwig Hölder ('sein Buch $^{41}[\ldots]$ gelangt aber nicht zu einem eigenen Standpunkt'), Torsten Brodén ('seine Arbeit ${ }^{42}$ [...] wenigstens in mathematischer Hinsicht ernsthafter Kritik nicht gewachsen sein dürfte') and Julius König ('entwickelte ${ }^{43}$ noch vor Hilbert ein rein formales System [...] allerdings ist das formale System sehr wenig umfassend und diese Betrachtungen nehmen nur einen sehr kleinen Teil des Buches ein'-1934, p. 57). Then, he specified that in France a school of philosophers had been formed and they considered mathematics from an empirical viewpoint, ${ }^{44}$ and suggested Émile Meyerson's book Du Cheminement de la Pensée as a survey of all of them

\footnotetext{
${ }^{38}$ About the personal contacts between Gödel and Heyting see also van Atten and Kennedy 2009, pp. 501-503 and van Atten 2015, pp. 191-193.

${ }^{39}$ In the correspondence between the two authors the labels 'logistic' and 'logicism' were used as interchangeable.

${ }^{40}$ Including the semi-intuitionists Borel, Weyl and Kaufmann.

${ }^{41}$ Hölder 1924.

42 Brodén 1924.

${ }^{43}$ König 1914.

${ }^{44} \mathrm{He}$ added the remark that empirical had to be intended in the common philosophical sense and not in Borel's sense:

'[...] empiristischen Standpunkt (im üblichen philosophischen Sinn, nicht im Sinn Borels)' (Heyting 1934, p.58).
} 
(by specifying : 'der selbst eine Vermittelnde Stellung zwischen Empirismus und Apriorismus einnehmen will' 1934, p. 58). The page devoted to Mannoury had been written by Mannoury himself, ${ }^{45}$ and at the end Moritz Pasch's so called 'empirism' ${ }^{46}$ was quickly described.

It is interesting to emphasize that Heyting mentioned 'semi-intuitionists'. ${ }^{47}$ As we have mentioned above, we find the label 'semi-intuitionism' in the Gödel's letter August 1931 for the first time, where he gave Heyting the semi-intuitionistic direction: 'Was die halbintuitionistische Richtung betrifft (Borel, Weyl 'Das Kontinuum' etc., so möchte ich gleichfalls vorschlagen, daß sie von Ihnen behandelt wird' (Gödel 2003, p. 36). Then, we find such label in the final version of the book: in the first part of the book (committed to intuitionism), the first chapter is dedicated to Poincarè's influence and the second to 'Die franzoesischen Halbintuitionisten'. Two further (short) chapters are dedicated to Weyl resp. and to Kaufmann before the beginning of the longest chapter, obviously committed to Brouwer. We see that Heyting did not insert Weyl among the semi-intuitionists as Gödel had suggested. Heyting defined the essence of 'intuitionism' as the belief in two 'Grundsaetze': 1) mathematics has also a contenutistic meaning ('inhaltliche Bedeutung'); 2) mathematical objects are directly grasped by a thinking spirit ('denkenden Geist'), therefore, mathematical knowledge is independent of experience ('Erfahrung'). Poincaré was described as a forerunner of intuitionists because he thought that mathematical induction had a content and 'forced us with necessity'; still he was only a forerunner and not a complete intuitionist, because he assigned to consistency proofs the value of proofs of existence of mathematical objects (like Hilbert). Then, Heyting specified that there were some authors who, referring to the second Grundsatz of intuitionism, believed that mathematical objects had an autonomous existence but they would only recognize them after building the objects. Such viewpoint was called by him 'Halb-intuitionism' (1934, p. 4). He stated that many authors shared such belief: Kronecker, Borel, Lebesgue, Baire, Kaufmann, Skolem, Richard. He committed the following chapter to French intuitionists, by calling them also 'Empiristen', according to Borel's self-definition as 'empiriste ou réaliste' (Borel 1928, p. 169). Heyting stressed that the above mentioned authors shared such belief, but then had very different viewpoints: for instance, Hadamard could have been called 'idealist' and Baire 'realist'.

Therefore, we can state that in his 1934 Mathematische Grundlagenforschung. Intuitionismus. Beweistheorie, Heyting showed that he acknowledged the tri-partition of the foundational schools, but at the same time he showed oscillation in terminology, an openness about the possibility of other schools and doubts in attaching labels to research projects.

\section{2. 'Spanningen in de wiskunde'}

In his 1949 inaugural address 'Spanningen in de wiskunde' ('Tensions in Mathematics'), Heyting described a formal attitude in the foundations of mathematics which Frege tried to do and Hilbert bettered. He did not use either 'logistic' or 'logicism' to distinguish them. He affirmed that the axiomatic method (that accompanied our history from Euclid on) could not give a foundation for mathematics, because axioms themselves required a justification. Therefore, axiomatics put the foundational questions and answered in formalistic terms: 'Hilbert is dan vrij spoedig tot een formalistisch stanpunt gekomen (Hilbert arrived quite soon to a formalistic standpoint)' (1949, p. 9). He added that Frege had already reached a formalistic construction of mathematics, in which mathematics was considered a part of logic. His system had produced antinomies, therefore Hilbert constructed his own, by keeping logic and mathematics in parallel in the same system, looking for a proof of non-contradictoriness. Gödel proved that such proof could not be found inside the system itself or in a weaker one. In the meantime, Brouwer had given an intuitionistic foundation of mathematics. Yet, many intuitionistic

\footnotetext{
45 Mannoury expressed his point of view both relativist and pragmatist (as in 1909). He added the necessity of a preliminary significist analysis before considering foundations of mathematics. He depicted his own position as an attempt to conciliate intuitionism and logicism (Heyting 1934, pp. 65-66).

${ }^{46}$ Heyting stressed (1934, p.59) that Pasch himself chose the label 'empirism', although in a sense different from the usual one. Pasch stated that mathematics should refer to sensible experience and point both its Kernbegriffe and its Kernsätze out of it, by paying attention that the Kerngebriffe be so clear to avoid any misunderstanding and the Kernsätze express experiences ('Erfahrungstatsachen') simple enough to be tested by anybody in his/her daily life.

47 About the use of the labels 'semi'/'pre-intuitionism' for Poincaré, Borel and Lebesgue in Brouwer see Michel 2008. About Poincaré's influence on 'contemporary intuitionists' supposed by Heyting see Heinzmann and Nabonnand 2008.
} 
notions appeared not to be so clear in the eyes of other intuitionists ${ }^{48}(1949$, p. 13): 'Aan verschillende delen van de intuitionistische wiskunde komt dus een verschillende grad van evidentie toe (to different parts of intuitionistic mathematics belong different degrees of evidence)'.

He stressed that no foundational viewpoint is exempt from criticisms, and each of them left many philosophical questions. According to him (1949, p. 17), the best solution was a method

die hed midden houdt tussen die van de vakwiskundigen en die van de filosofen, namelijk deze, dat men tracht, zich het wiskundige denkproces zo zuiver en helder mogelijk tot bewustzijn te brengen, zonder er bepaalde metaphysische of psychologische interpretaties van te geven (that is halfway between that of the specialist disciplines and that of philosophers, i.e. this, that one tries to bring to consciousness the mathematical process as pure and clear as possible, without giving certain metaphysical or psychological interpretations.

We should take mathematics as it was, without idealizing it. In particular, intuitionistic mathematics was an 'activity of the spirit' ('geestelijke activiteit') to which many people contributed, and they communicated both through the daily language and symbolic language. At the end he asked if (and why) intuitionistic mathematics was worthwhile. He doubted that it could be useful in natural sciences, yet, if intuitionism were put in a fruitful relationship ('vruchtbare wisselwerking') with other forms of thought 'denkvormen', then high results were to be expected in both the logic and the theory of knowledge ('kentheoretici'). Heyting questioned worthiness, by keeping as an alternative the 'klassieke school'. This expression explains why he only used two labels 'formalism' and 'intuitionism': he saw intuitionistic mathematics (and logic) as very different from the earlier unique mathematics (and logic). Therefore, he considered only two contrasting groups: the ancient (where the foundational question begun and had been answered in formalistic terms) and the new (intuitionism).

\section{3. 'Sur la Tâche de la Philosophie des Mathématiques'}

In 'Sur la Tâche de la Philosophie des Mathématiques' (1953) he spoke of 'partisans de la logistiques', 'mathématiciens croient que la rigueur ne se trouve que dans la manipulation de formules' and 'les intuitionnistes' as 'les courants de pensée plus modernes', but at the end of the paper he made a comparison only between the viewpoints of intuitionists and of formalists as representing (at a deeper insight) the two aspects which classical mathematics consisted of. He suggested, as a task for the philosopher of science, to point out that both the formalists and the intuitionists just developed one aspect of classical mathematics; they could not stand by themselves, separated by one another, but they both took care of aspects, none of which could be detached from mathematics (1953, p. 197):

Un mathématicien formaliste écrit des formules suivant des règles clairement formulées, mais le philosophe portera son attention également sur les judgements de valeur que le formaliste fait sur son système, et sur l'intérpretation tacite qui le guide dans la construction du système. De même, quand l'intuitionniste pretend s'interesser exclusivement aux constructions mentales, le philosophe observera qu'il fait tout de même des calculs formels et se demandera quel est le role du calcul dans la conception intuitionniste (A formalist mathematician writes formulas according to clearly formulated rules, but the philosopher will also focus on the value judgements that the formalist expresses in his system, and on the tacit interpretation that guides him in the construction of the system. Similarly, when the intuitionist pretends to be interested exclusively in mental constructions, the philosopher will remark that he himself has made formal calculations and wonders what is the role of the calculation inside the intuitionistic viewpoint).

\subsection{Intuitionism: an Introduction}

In his 1956 Intuitionism: an Introduction, at the very beginning Heyting proposed a dialogue between a classical logician, a formalist, an intuitionist, a 'letteralist', a pragmatist, a representant of the Signific. The dialogue was centered around the possible criticisms to intuitionism, but the criticisms were expressed by well

\footnotetext{
${ }^{48}$ See Griss' criticism of the notion of negation (Franchella 1994) for instance.
} 
specified 'sources' that - in some cases - also described their own opinion. No 'logicist' appeared under this label. A strong hint of Carnap was apparent, and he was directly quoted but under the label 'formalism'. The classicist pointed out the following criticisms:

1) Intuitionistic mathematics could not be seen as the whole mathematics but only as a part of classical mathematics. ${ }^{49}$

2) Intuitionistic mathematics believed to do without logic, but it built castles in the air if it would not have the firm ground that only logic could offer..$^{50}$

3) Intuitionistic mathematics presented 'truths' that were not absolute (i.e. eternal, valid in any time), but that began to be valid at the moment in which, for instance, a certain object was built by satisfying a given property. ${ }^{51}$

The letteralist defined his viewpoint about mathematics: 'Mathematics is quite a simple thing. I define some signs and I give some rules for combining them; that is all'. He did not need proof of consistency for their formal systems because these were directly confronted with applications and in general they proved to be useful. This would be 'difficult to explain if every formula were deducible in them' (1956, p. 7). He criticized intuitionism for the following reasons:

1) Intuitionism accepted the infinite in mathematics (even if in its potential form), but clarity could be reached only by remaining in the finite..$^{52}$

2) Intuitionism had a dogmatic character because it accepted some principles (for instance, complete induction) and refused some others (for instance, the principle of excluded middle), even if most people considered all of them as evident. ${ }^{53}$

3) Intuitionism had a 'theological character' because mathematical intuition inspired it with objective and eternal truths. ${ }^{54}$

The significist criticized intuitionism for its reluctance towards formalization, which was the ideal of the modern scientist and was, according to him, the only access to mental constructions. ${ }^{55}$

The pragmatist agreed with the significists and added: 'The ideal of modern scientist is to prepare an arsenal of formal systems ready for use from which he can choose, for any theory, that system which correctly represents the experimental results'.

The formalist criticized intuitionism for the following reasons:

1) Neither terms nor derivation rules were well defined: therefore, the risk of misunderstanding was high. ${ }^{56}$

\footnotetext{
${ }^{49}$ Heyting replied that intuitionistic mathematics had a different object with respect to classical mathematics. In any case, he was open to recognizing the existence of different possible objects for different mathematics. He did not intend to consider intuitionistic mathematics as an absolute.

${ }^{50}$ Heyting stressed that also logic itself would need a firm ground at its turn.

${ }^{51}$ Heyting answered that believing in something that had not yet been constructed would involve a series of metaphysical difficulties that could be avoided only by banishing such 'entities' from mathematics (1956, p.3)

${ }^{52}$ Heyting pointed out that even children in the elementary school could understand what the natural numbers were and they accepted the fact that the sequence of natural numbers could be indefinitely continued (1956, p. 7). He did not claim certainty or definiteness in absolute sense - which would be unrealizable - but he contended that it was sufficiently clear to build mathematics upon.

${ }^{53}$ Heyting underlined that 'evidence' meant 'mental construction', which anybody was supposed to be able to carry on.

${ }^{54}$ Heyting rebutted that intuitionistic mathematics had to do with mental constructions and everybody were convinced that other people could build mental constructions analogous to our own.

55 Heyting admitted that, if the trend of science would really be the formalization of language, then intuitionistic mathematics did not belong to mathematics in this sense of the word, but it would rather be a natural activity of man. Yet, it seemed to him that usefulness was not the only measure of value. For instance, an artistic product would be highly valued, although in most cases it was useless.

${ }^{56}$ Here Heyting did not answer directly, but he affirmed that they both were interested to that type of reasoning that appeared in metamathematics and they specifically limited themselves to it because they were deeply convicted that 'we find here one of the most fundamental faculties of the human mind' (1956, p.4).
} 


\section{2) It destroyed a large part of classical mathematics. ${ }^{57}$}

It is very interesting that the intuitionist stated at the very beginning $(1956, \mathrm{p} .1)$ that mental mathematical constructions were objects that required their 'own' logic, i.e. intuitionistic logic. We can interpret this as an application of Carnap's principle of tolerance. Heyting referred to it later, by letting it be quoted by the so called formalist. In particular, when the intuitionist affirmed that the difference between formalists and intuitionists was mainly one of tastes, the formalist replied: ${ }^{58}$ 'If you will not quarrel with formalism, neither will I with intuitionism. Formalists are among the most pacific of mankind. Any theory may be formalized and then becomes subject to our methods. Also intuitionistic mathematics may and will be treated' (1956, p. 4). The direct reference to Carnap 1934 and 1937 was put inside this quote. ${ }^{59}$

It is useful to compare this reference to the difference between intuitionists and formalists as a matter of taste with the same reference mentioned above in Brouwer 1928. Brouwer's reference was 'under condition': if (and only if) the formalists accepted his four conditions, then the difference between the two schools would have become a matter of taste. Such conditions would have changed the essence of the formalist viewpoint: there wouldn't be any differences between them and the matter of taste would not have concerned the acceptance of a viewpoint (instead of another) but simply the choice of a label (instead of another) for the same viewpoint.

\section{5. 'Blick von der intuitionistischen Warte' and 'On Truth in Mathematics'}

In 1958 Heyting published 'Blick von der intuitionistischen Warte' and 'On Truth in Mathematics'. In the first paper he stated that classical mathematics was a 'merkwürdige Mischung sehr heterogener Bestandteile' (1958a, p. 338). Intuitionism and formalism had pointed out two of those aspects, i.e. the formal side and the part that was based on number-intuition. They were in error when each believed to be 'die einzig Richtige': formal mathematics always contains a remnant of intuition, while the intuitionistic cannot do without the use of formulas. Still, there was a third direction, the platonistic one, consisting in the belief in the existence of a world of mathematical objects. It was refused by the first two directions; nevertheless, the majority of mathematicians insisted on this conception; they use the classical proof procedures without considering them as purely formal developments.

In 'On truth in mathematics' he presented a tripartition of classical mathematics again, by specifying that the component that he 'should like to call the naïve, but which was often called the platonic one' (1958b, p. 277) was shared by the mathematicians until 1900s, then it was put in doubt by the discovery of paradoxes, by Hilbert and by Brouwer. According to Heyting, the assumption of an abstract reality of any sort was

\footnotetext{
${ }^{57}$ Heyting replied that mutilations of mathematics could be seen as the excision of noxious ornaments and they were however partly compensated for by the charm of subtle distinctions that intuitionists had introduced (1956, p. 11).

${ }^{58}$ Maybe Heyting put Carnap's quotes in the mouth of the formalist, because he considered Carnap's position essentially different from logicism just in reason of his principle of tolerance: while logicism believes in only one logic, Carnap presented a catalogue of possible logics. Carnap style is also traceable in the criticism that the intuitionist did to the classicist during the debate about the meaning of 'existence' in mathematics by stating: 'Your argument is metaphysical in nature'. He did not exclude metaphysics as such, but only in the practice of mathematics (1956, p. 2):

We have no objection against a mathematician privately admitting any metaphysical theory he likes, but Brouwer's program entails that we study mathematics as something simpler, more immediate than metaphysics. In the study of mental mathematical constructions 'to exist' must be synonymous with 'to be constructed'. [...] In fact all mathematicians and even intuitionists are convinced that in some sense mathematics bears upon eternal truths, but when trying to define precisely this sense, one gets entangled in a maze of metaphysical difficulties. The only way to avoid them is to banish them from mathematics.

Carnap was quoted also as a reference for the formalist's criticism on the purpose of vagueness of definitions. It is interesting to stress that on the quoted page Carnap (1934, p.41) had labelled Poincaré, Brouwer, Weyl, Heyting, Becker, Kaufmann and Wittgenstein as 'strict finitists'. Heyting didn't use that label because he described the position of the 'letteralist' as strict finitist and put the name of Curry under that label (1956, p. 8).

59 ' [...] das Toleranzprinzip: wir wollen nicht Verbote aufstellen, sondern Festsetzungen treffen. [...] In der Logik gibt es keine Moral. Jeder mag seine Logik, d.h. seine Sprachform aufbauen wie er will' (1934, pp. 44-45).
} 
meaningless, yet 'It seems to be increasing nowadays, under the influence of the successes of the semantic school, under the leadership of Tarski' (1958b, p. 278).

\section{6. 'After thirty years'}

In 1962, as we expect from the title 'After thirty years', Heyting referred to the Königsberg Conference, hence he mentioned logicism, by stressing that in 1931 logicism had to solve more of a technical problem than one of fundamental nature (1962, p. 194), i.e. eliminating the axiom of reducibility without adopting Ramsey's Platonism. Then, he discussed both logicism and formalism in a few words (1923, p. 195):

None of the conceptions of mathematics is today as clear-cut as it was in 1930. I shall be short about formalism and logicism. Formalism is the least vulnerable, but for metamathematical work it needed some form of intuitive mathematics. As to logicism, many axiomatic systems of logic and of set theory compete. It has proved not to be intuitively clear what is intuitively clear in mathematics. It is even possible to construct a descending scale of grades of evidence.

Finally, he committed himself only to intuitionism. He added that 'intuitive, formal, logical and platonic' elements inside mathematics had been recognized.

\section{7. 'Wijsbegeerte de Wiskunde'}

In his 1968 paper 'Wijsbegeerte de Wiskunde' ('Philosophy of Mathematics'), Heyting offered a review that started from Cantor and Frege, included Hilbert and Brouwer but also Mannoury and a brief reference to E.W. Beth. He considered Cantor and Frege inside a unique chapter under the title 'Set theory and logic', stressing that Frege's Begriffe (concepts) corresponded to Cantor's sets. Heyting mentioned Frege's logicism and the paradoxes that affected it. He stated that, even if both Russell and Quine solved them, there could be no warranty that some other paradox could emerge. This was the question that Hilbert had already done in 1900 at the Paris congress (Hilbert 1900b) in his list of the mathematical problems to solve in the twentieth century: is there a proof that mathematics and logic are consistent? Therefore, Heyting delt with Hilbert's way to handle that problem in the following chapter. As for Mannoury, Heyting stressed his engagement in signific and referred that the movement analysed the 'taaldaden' ('linguistic facts'), consisting of two meanings, that of the speaker and that of the hearer. The first were thought and emotions that the speaker wanted to transmit; the latter were the effects of the first. Heyting recalled two concepts of the signific analysis that seemed to be of substantial relevance to him: 1) 'taaldualiteit', i.e. the distinction between indicative and volitional elements of the meaning, which were expressed resp. in the 'het-taal' ('it-language') and in the 'ik-taal' ('I-language'); 2) 'taalpolariteit' ('the polarity of language'), consisting of the particular and the limited on the one side, and of the general and the universal on the other side (1968, p. 147). A confusion of elements of het-taal and iktaal should be avoided. Many problems came out in philosophy on the basis of this confusion (for instance, the question 'what is the aim of the world' mixed up 'world' that belonged to the het-taal and 'aim' that belonged to the ik-taal). Heyting saw in this a similarity with neopositivism but 'without limiting language to communicating only the scientific results'; 3 ) the scale of languages according to the relevance that syntactical relations gained. The top took place in formalised languages, like formalised mathematics (or logic), ${ }^{60}$ that had neither an indicative nor an emotional meaning: it fell outside the duality of language, while in the polarity of language it was collocated on the universal side. The passage from one level to another was always gradual. Mannoury considered impossible to found mathematics on an absolutely sure ground. Finally, Heyting explained the two significist ways of observing the mathematical language: the analytical way (consisting in observing the forms of language and the psychological associations linked to them that should be counted to mathematics in order to characterise it at best) and the synthetic way (consisting in putting conditions that a mathematical language has to satisfy and then trying to develop such a language). In no case a definitive result

\footnotetext{
${ }^{60}$ Heyting also referred to Mannoury's distinction between choice-negation (that took place between two oppositions cold/hot) and exclusion negation (that did not propose an alternative, like the negation present in the concept of infinite) (1968, p. 148).
} 
could be obtained, because it depended on the conscious and unconscious associations that were outside mathematics.

As for Beth, he stressed that his philosophy of mathematics was more a program than a complete theorization, consisting of a conceptual realism that distinguished four spheres of reality (the physical reality - the world of matter; the social reality - the world of men; the subjective reality - the world of the spirit; the logical reality - the world of 'redenering'). Mathematics would belong to the last sphere. Heyting also recalled Beth's methodology: the critical research ('onderzoek') of concepts and methods of science, both 'van binnen uit' (i.e. of the science from the inner, as the science is) and 'van buiten' ('from the outside'), through a general philosophy. His work in logic and philosophy of mathematics was a part of the first kind of analysis. Heyting stressed that the author himself had admitted that a lot of work was still necessary before getting to a 'filosofische synthese' (1968, p. 151).

\section{8. 'Intuitionistic Views about the Nature of Mathematics'}

In 1974, in presenting intuitionistic views about mathematics, Heyting wrote only about intuitionism and formalism by stating that intuitionism described mathematical thought while formalism could only offer a linguistic structure. He specified that, looking for a basis of mathematics which 'is directly given and which we can immediately understand without philosophical subtleties' $(1974$, p. 80$)$, the first which presented itself was the process of counting. An analysis of it led us to the simplest function of our mind: isolating an object. In reality, - Heyting said - we do not isolate objects but perceptions: 'I can fix my attention on a certain impression, in most cases visual' (1974, p. 80) ${ }^{61}$ By creating an entity, another entity, still another entity, etc., we mentally construct natural numbers. It is clear that all conscious thinking can be considered as applied mathematics. As soon as numerals were introduced, people learnt to abstract from the content of the perceptions which were isolated and to consider them as pure entities. Heyting was conscious that some problems arose when people tried to communicate their mental constructions to others: he affirmed that we can only be sure when referring to small natural numbers. In this context he compared intuitionism to 'the most radical form of formalism', that he described in the following way $(1974$, p. 89):

The formalist considers every intuitive mathematical reasoning as inexact. He studies the language in which such reasonings are expressed and tries to formalize them. The result is a formal system consisting of a finite number of symbols and a finite number of rules for combining them into formulas.

The result of the comparison was (Ibidem):

There is no conflict between intuitionism and formalism when each keeps to its own subject, intuitionism to mental constructions, formalism to the construction of a formal system, motivated by its internal beauty or by its utility for science and industry. They clash when formalists contend that their systems express mathematical thought. Intuitionists make two objections against this contention. In the first place, as I have argued, just now, mental constructions cannot be rendered exactly by means of language; secondly the usual interpretation of the formal system is untenable as a mental construction.

In this perspective, logic would be either a part of mathematics (if we interpreted syllogisms in term of set theory) or applied mathematics (if we interpreted syllogisms in terms of truth-value of linguistic expressions). The paper ended with a gradualist vision of the various aspects of culture. At the lowest (and commonest) level there was the creation of a finite number of individual entities and the relations between them. The mathematical systems used in modern physics were enormously more refined than those that were at the basis of history, but also the work of the historian consisted in establishing relations between the facts that he had isolated in the continuous stream of events.

${ }^{61}$ Heyting specified (1974, p. 80):

When we think, we think in entities. This does not mean that all our mental life consists of thinking in entities. On the contrary, the more intensely we live, the less we think in isolated entities. Under the influence of strong emotions the world seems a whole, loaded with emotion. Only after the emotions are soothed we map out aims and ways to attain them. 


\section{9. 'History of the Foundations of Mathematics'}

In 'History of the Foundations of Mathematics' of 1978, which covered a time spread till 1940, Heyting described the basic steps of the subject (formalization of logic, the paradoxes of set theory, type theory, proof theory) and the so-called 'dramatic events' (the discovery of Russell's paradox and Gödel's theorems); at the end, he presented the three Dutch figures of Brouwer, with two final chapters committed to intuitionistic topics (choice sequences and 'the continuum as a spread'), Beth, and Mannoury (both of them very briefly). As for Beth, he recalled his main contributions to logic, i.e. Beth's theorem (the theorem 'on the reduction in a formal system of an implicit definition to an explicit definition') and the method of semantic tableaux (1978, p. 6). As for Mannoury, he only specified that his personal philosophy was that of Significs, based on psychological investigation of linguistic intercourse, and that it led him to a relativistic opinion that doubted even mathematical exactness. Heyting added (1978, p. 15) some remarks about his own contributions:

My papers on the formalization of intuitionistic logic and mathematics [...] I regret that my name is known to-day mainly in connection with these papers [...] They diverted the attention from the underlying ideas to the formal system itself'.

He concluded (1978, p. 15) with his observations about the situation of intuitionism at that time:

The editors of this collection decided to delimit it to the years before 1940. Still I cannot end without remarking that afterwards the situation has completely changed. It is generally recognised that intuitionism makes sense and that it is worthwhile to study it. The controversy between intuitionism and formalism has been solved. Dutch workers on foundations are no longer isolated; they collaborate intensively with their colleagues all over the world.

\subsection{Final remarks}

It is clear from all these quotes that Heyting firmly believed that intuitionism was the right foundation of mathematics. Yet, he was very respectful of other opinions and believed that collaboration amongst mathematicians was highly relevant. He was open to new ideas, new results and new projects. Furthermore, it is also clear from the analysis of all his foundational papers that Heyting did not see the foundational schools as three clear-cut stones, but in the foundational panorama he examined many suggestions that could have been or could not have been suitable for existing labels. The suggestions could be presented under the name of the proponent or under an old label or a newly coined one. I think that these two aspects (openness to others' points of view and freedom in labelling) were linked: his frequent changes in presenting the foundational schools, his description of a broad range of them and his freedom in labelling were signs of his openness towards other points of view and of his will to avoid rigid contrapositions among them. By contrast, Brouwer's constant use of only two labels to describe the foundational panorama was a sign of his will to absolutize his viewpoint: all the possible nuances of other perspectives were collected under a unique label in the perspective of a final duel that should have led to a definitive victory.

\section{Acknowledgements}

I am very grateful to Shirlej Gabbai for all the help she offered me during the final revision of this article.

\section{Bibliography}

Allen, E.S. 1933. 'Dubislav on Foundations', Bulletin of the American Mathematical Society 39, 329-32. van Atten, M. 2015. Essays on Gödel's Reception of Leibniz, Husserl, and Brouwer, Heidelberg: Springer. 
van Atten, M. 2017. 'The Development of Intuitionistic Logic', The Stanford Encyclopedia of Philosophy, E. N. Zalta ed., <https://plato.stanford.edu/archives/win2017/entries/intuitionistic-logic-development/>

van Atten, M. and Kennedy, J. 2009. 'Gödel's logic', in D.M. Gabbay and J. Woods, eds., Handbook of the History of Logic, vol. 5, Amsterdam: North-Holland, 449-509.

van Atten, M. and Sundholm, G. 2017. 'L.E.J. Brouwer's Unreliability of the Logical Principles: A New Translation, with an Introduction', History and Philosophy of Logic, 38 (1), 24-47.

Borel, É. 1928. Leçons sur la théorie des fonctions. 3ème edition, Paris: Gauthier-Villars.

Brodén, T. 1924. 'Eine realistische Grundlegung der Mathematik', Lunds Universitets Årsschrift N.F. Avd. 2, $\operatorname{Bd} 20(\mathbf{1})$.

Brouwer, L.E.J. 1907. Over de gronslagen der wiskunde, Amsterdam: Mass and van Suchtelen; Engl. Transl. On the Foundations of Mathematics, in Brouwer 1975, 11-101.

Brouwer, L.E.J. 1908. 'De Onbetrouwbaarheid der Logische Principes', Tijdschrift voor Wijsbegeerte 2, 152-

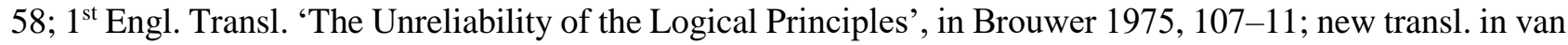
Atten and Sundholm 2017, 37-44.

Brouwer, L.E.J. 1911. 'Review of: G. Mannoury, Methodologisches und Philosophisches zur ElementarMathematik (Haarlem 1909)', Nieuw Archief voor Wiskunde (2) 9, 199-201; excerpts in Brouwer 1975,12122.

Brouwer, L.E.J. 1912. 'Intuitionisme en Formalisme', Wiskundig Tijdschrift 9 (1913), 180-211; Engl. Transl. 'Intuitionism and Formalism', Bulletin of the American Mathematical Society 20, 81-96 and in Brouwer 1975, $123-38$.

Brouwer, L.E.J., 1924, 'Über die Bedeutung des Satzes vom ausgeschlossenen Dritten in der Mathematik, insbesondere in der Funktionentheorie', Journal für die reine und angewandte Mathematik, 154, 1-7. English translation in van Heijenoort 1967, 335-41 and in Brouwer 1975, 268-74.

Brouwer, L.E.J. 1928. 'Intuitionistische Betrachtungen über den Formalismus', Koninklijke Nederlandse Akademie van Wetenschappen Proceedings 31, 374-79; also in Brouwer 1975, 409-15.

Brouwer, L.E.J. 1929. 'Mathematik, Wissenschaft und Sprache', Monatshefte Mathematik 36, 153-64, also in Brouwer 1975, 417-28.

Brouwer, L.E.J. 1930. 'Die Struktur des Kontinuums', Wien; also in Brouwer 1975, 429-40.

Brouwer, L.E.J. 1952. 'Historical Background, Principles and Methods of Intuitionism', South African Journal of Sciences 49, 139-46.

Brouwer, L.E.J. 1954. 'Points and spaces', Canadian Journal of Mathematics 6, 1-17; also in Brouwer 1975, 522-38.

Brouwer, L.E.J. 1975. Collected Works 1, A. Heyting ed., Amsterdam, Oxford: North-Holland, quoted in the article as ' $C W I$ '.

Brouwer, L.E.J. 1981. Brouwer's Cambridge Lectures on Intuitionism, D. van Dalen ed., Cambridge: Cambridge University Press.

Brouwer, L.E.J. 1991. Intuitionismus, D. van Dalen ed., Mannheim, Leipzig, Wien, Zürich: BI Wissenschaftsverlag.

Busse, L. 1903. 'Review of Edmund Husserl Logische Untersuchungen', Zeitschrift für Psychologie und Physiologie der Sinnesorgane 33, 153-57. 
Carnap, R. 1929. Abriß der Logistik mit besonderem Berücksichtigung des Relationstheorie und ihre Anwendungen. Berlin: Springer.

Carnap, R. 1930. 'Die alte und die neue Logik', Erkenntnis 1 (1930/1931), 12-26.

Carnap, R. 1931. 'Die logizistische Grundlegung der Mathematik', Erkenntnis 2 (1931), 91-105.

Carnap, R. 1934. Logische Syntax der Sprache, Wien: Springer.

Carnap, R. 1937. The Logical Syntax of Language, London: K. Paul, Trench, Trubner \& Co.

Clausberg, W. and Dubislav, W. 1923. Systematisches Wörterbuch der Philosophie, Leipzig: Meiner.

Couturat, L. 1904. 'Deuxième Congrès International de Philosophie', Revue de Metaphysique et de Morale 12, 1037-77.

Couturat, L. 1905. 'Sur l'Utilité de la Logique Algorithmique' in E. Claparède, ed., Congrès International de Philosophie, IIme session, Genève: H. Kündig, 706-11.

van Dalen, D. 1990. 'The War of the Frog and the Mice, or the Crisis of the Mathematische Annalen', The Mathematical Intelligencer 12, 17-31.

van Dalen, D. 2000. 'Brouwer and Fraenkel on Intuitionism', Bulletin of the Association of Symbolic Logic 6, 284-310.

Dubislav, W. 1926. 'Über das Verhältnis der Logik zur Mathematik', Annalen der Philosophie und philosophischen Kritik 5, 193-208.

Dubislav, W. 1930. 'Über den sogenannten Gegenstand der Mathematik', Erkenntnis 1, 27-48.

Dubislav, W. 1931. 'Die sogenannte Grundlagenkrise der Mathematik', Unterrichtsblätter für Mathematik und Naturwissenschaft 37, 146-52.

Dubislav, W. 1932. Die Philosophie der Mathematik in der Gegenwart, Berlin: Junker und Dünnhaupt.

Franchella, M. 1994. 'Brouwer and Griss on Intuitionistic Negation', Modern Logic 4, 256-65.

Fraenkel, A. 1928. Einleitung in die Mengenlehre. 3rd edition, Berlin: Springer.

Frege. G. 1884. Die Grundlagen der Arithmetik. Eine logisch mathematische Untersuchung über den Begriff der Zahl, Breslau: W. Koebner.

Frege. G. 1893. Die Grundgesetze der Arithmetik. Begriffschriftlich abgeleitet, 1. Band, Jena: H. Pohle.

Frege, G. 1903. 'Über die Grundlagen der Geometrie', Jahresbericht der Deutschen Mathematiker Vereinigung 12, 319-24 and 368-75.

Gödel, K. 2003. Collected Works, Volume V, Correspondence H-Z, S. Feferman et al. eds., Oxford: Clarendon Press.

Grattan-Guinness, I. 2000. The Search for Mathematical Roots 1870-1940, Princeton, Oxford: Princeton U.P.

Groos, K. 1912. 'Untersuchungen über den Aufbau de Systeme', Zeitschrift für Psychologie 62, 241-75.

van Heijenoort, J. 1967. From Frege to Gödel, Cambridge Mass.: Harvard U.P.

Heinzmann, G. and Nabonnand, P. 2008. 'Poincaré: Intuitionism, Intuition, and Convention', in M. van Atten, P. Boldini, M. Bourdeau, and G. Heinzmann eds., One Hundred Years of Intuitionism (1907-2007), Basel: Birkhauser, 163-77. 
Heijerman, A. F. 1990. 'Relativism and Signific: Gerrit Mannoury and the Foundations of Mathematics', in H. W. Schmitz ed., Essays on Significs, Amsterdam: Benjamins, pp. 247-72

Heyting A. 1925. Intuitionistische Axiomatiek der Projectieve Meetkunde. Groningen: Noordhoff; also in Heyting 1980, 1-104.

Heyting, A. 1931. 'Die intuitionistische Grundlegung der Mathematik', Erkenntnis 2, 106-15; also in Heyting 1980, 240-50.

Heyting, A. 1934. Mathematische Grundlagenforschung. Intuitionismus. Beweistheorie, Berlin: Springer.

Heyting, A. 1949. 'Spanningen in de Wiskunde', Euclides 25, 233-36; 301-12; also in Heyting 1980, 449-67.

Heyting, A. 1953. 'Sur la Tâche de la Philosophie des Mathématiques', in Proceedings of the XIth International Congress of Philosophy, Brussell, 20-26 August 1953, Amsterdam: North-Holland, 193-98; also in Heyting 1980, 497-512.

Heyting, A. 1956. Intuitionism: an Introduction, Amsterdam: North-Holland.

Heyting, A. 1958a. 'Blick von der intuitionistischen Warte', Dialectica 12, 332-45; also in Heyting 1980, 560-73.

Heyting, A. 1958b. 'On Truth in Mathematics', in Verslag van de Plechtige Viering van het Honderdvijftig Jarig Bestaan der Koninklijke Nederlandse Akademie van Wetenschappen met de Teksten der bij die Gelegenheid Gouden Redevoering en Voordrachten, Amsterdam: North-Holland, 277-79; also in Heyting 1980, 574-76.

Heyting, A. 1962. 'After Thirty Years', in Nagel, E., Suppes, P., and Tarski, A. eds. Logic, Methodology and Philosophy of Science, Stanford: Stanford U.P., 194-97; also in Heyting 1980, 640-43.

Heyting, A. 1968. 'Wijsbegeerte van de Wiskunde', Algemeen Nederlandse Tijdschrift voor Wijsbegeerte en Psychologie 60, 140-53; also in Heyting 1980, 711-24.

Heyting, A. 1974. 'Intuitionistic Views on the Nature of Mathematics', Bollettino dell'Unione Matematici Italiani 9, 122-34; also Synthese 27 (1974), 79-91; also in Heyting 1980, 743-55.

Heyting, A. 1978. 'History of the Foundations of Mathematics', Nieuw Archief voor Wiskunde $3^{\text {rd }}$ series, 26, 1-21; in Heyting 1980, 765-85.

Heyting, A. 1980. Collected Papers, A.S. Troelstra, J. Niekus, and H. van Riemsdijk eds., Amsterdam: Mathematical Institute, University of Amsterdam.

Hesseling, D.E. 2003. Gnomes in the Fog. The Reception of Brouwer's Intuitionism in the 1920s, Basel, Boston, Berlin: Birkhäuser.

Hilbert, D. 1899. Die Grundlagen der Geometrie, Leipzig: Teubner.

Hilbert, D. 1900a. 'Über den Zahlbegriff', Jahresbericht der Deutschen Mathematiker Vereinigung 8, 18084.

Hilbert, D. 1900b. 'Mathematische Probleme', Nachrichten von der Königlichen Gesellschaft der Wissenschaften zu Göttingen 1900, 253-97 and Archiv für Mathematik und Physik 1 (1901), 44-63; 213-37.

Hölder, O.L. 1924. Die mathematische Methode: Logisch erkenntnistheoretische Untersuchungen im Gebiete der Mathematik, Mechanik und Physik, Berlin: Springer.

König, J. 1914. Neue Grundlagen der Logik, Arithmetik und Mengenlehre, Leipzig: von Veit.

Krug, T. W. 1833. Allgemeines Handwörterbuch der philosophischen Wissenschaften nebst ihrer Literatur und Geschichte, Bd. II, 2. Ed., Leipzig: Brockhaus. 
Kuiper, J. 2004. Ideas and Explorations. Brouwer's Road to Intuitionism, Utrecht University. Available online at http://dspace.library.uu.nl/handle/1874/90.

Lewis, C.I. 1918. A Survey of Symbolic Logic, Berkeley: University of California Press.

Mancosu, P. 1998. From Brouwer to Hilbert. The Debate on the Foundations of Mathematics in the 1920s, New York: Oxford UP.

Mannoury, G. 1909. Methodologisches und Philosophisches zur Elementarmathematik, Haarlem: Visser.

Meinong, A. 1906-7. 'Über die Stellung der Gegenstandstheorie im System der Wissenschaften', Zeitschrift für Philosophie und philosophische Kritik 1906, 48-94, 155-207; 1907, 1-46; then printed as book Leipzig: Voigtländer.

Meyerson, É. 1931. Du Cheminement de la Pensée, Paris: Alcan.

Michel, A. 2008. 'Remarks on the supposed French "Semi-" or "Pre-intuitionism"', in M. van Atten, P. Boldini, M. Bourdeau, and G. Heinzmann eds., One Hundred Years of Intuitionism (1907-2007), Basel: Birkhauser, 149-62.

Milkov, N. 2015. 'On Walter Dubislav' History and Philosophy of Logic 36 (2), 147-61.

Milkov, N. 2016. 'Walter Dubislav's Philosophy of Science and Mathematics', Hopos: The Journal of the International Society for the History of Philosophy of Science 6(1), 96-116.

Oberdan, T. 1993. 'The Synthesis of Logicism and Formalism in Carnap's Logical Syntax of Language', in F. Stadler ed., Scientific Philosophy: Origins and Developments, Dordrecht: Kluwer, 157-68.

Parsons, C. 2003. 'Arend Heyting', in Gödel 2003, 23-33.

van Stigt, W.P. 1990. Brouwer's Intuitionism, Amsterdam: North-Holland.

Viète, F. 1691. In Artem Analyticem Isagoge, Mettayer.

Voss, A. 1908. Über das Wesen der Mathematik, Leipzig, Berlin: Teubner.

Wang, H. 1987. Reflections on Kurt Gödel, Cambridge Mass.: MIT.

Wundt, W.M. 1910a. Kleine Schriften Bd. 1, Leipzig: Engelmann.

Wundt, W.M. 1910b. 'Psychologismus und Logizismus', in Wundt 1910a, 511-634.

Van Zantwijk, T. 2013. "'Demonstrations" not "Deductions": Walter Dubislav on Transcendental Arguments', in N. Milkov and V. Peckhaus eds., The Berlin Group and the Philosophy of Logical Empiricism, Dordrecht: Springer, 191-204.

Ziehen, T. 1913. Erkenntnistheorie auf psychophysiologischer und physikalischer Grundlage, Jena, Fischer.

Ziehen, T. 1914. Zum gegenwärtigen Stand der Erkenntnistheorie: zugleich Versuch einer Einteilung der Erkenntnistheorien. Wiesbaden: J.B. Bergmann.

Ziehen, T. 1920. Lehrbuch der Logik auf positivistischer Grundlage mit Berücksichtigung der Geschichte der Logic, Bonn: Markus u. Weber.

http://www.gleichsatz.de/b-u-t/begin/wundt/wu-psylog1.html

http://www.stork-herbst.de/ziehen/t1914d/1914d.html\#_fnt405

http://www.rbjones.com/rbjpub/philos/glossary/logicism.htm 
http://www.cs.ru.nl/ freek/brouwer/ 